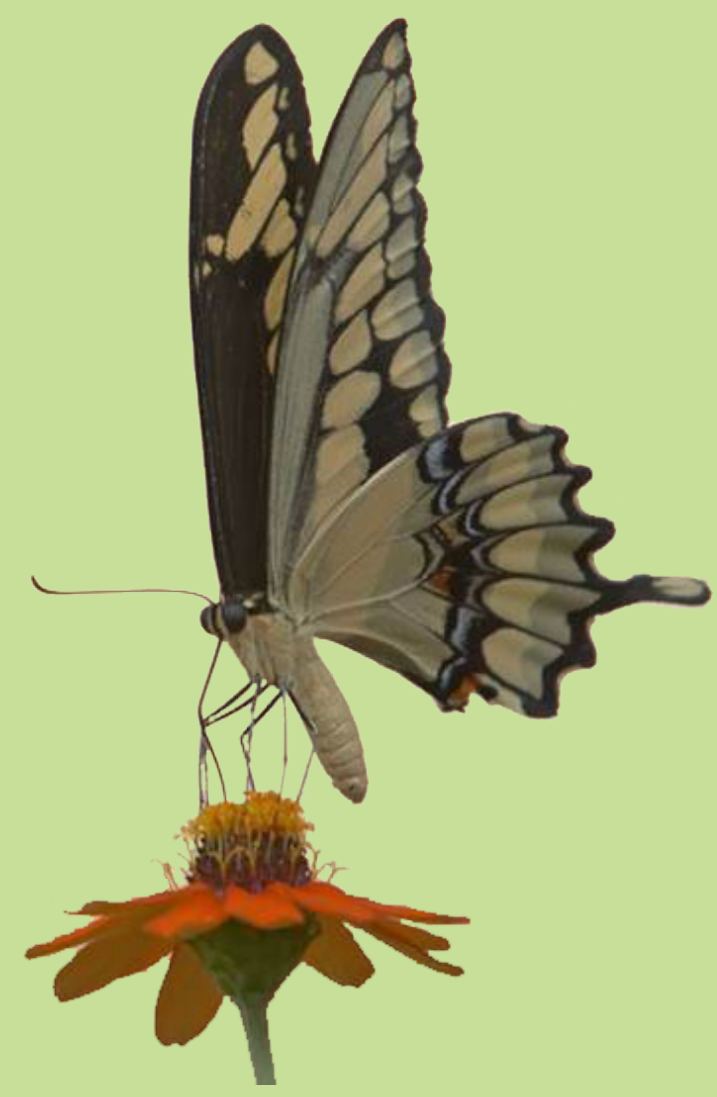

Erich Streissler 50 Years of Austrian Economics

KIOES Opinions 7 (2018)

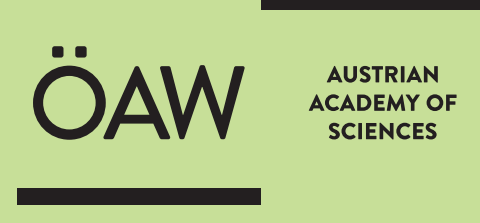


Commission for Interdisciplinary Ecological Studies (KIOES)

KIOES Opinions 7 (2018): 1-46.

\section{Erich Streissler 50 Years of Austrian Economics}

KIOES Opinions 7 (2018) 
KIOES Opinions 7 (2018): 1-46.

doi: 10.1553/KIOESOP_007

Imprint:

KIOES Opinions are published by the Commission for Interdisciplinary Ecological Studies (KIOES) of the Austrian Academy of Sciences (OeAW). KIOES publishes current opinions written, initiated or invited by KIOES related to topical subjects on an irregular basis in KIOES Opinions. The target audience includes scientists, policy makers and the public. Opinions expressed in this article are solely those of the author(s), and they do not necessarily reflect in any way those of KIOES or OeAW.

More information about KIOES and download of KIOES Opinions at http://www.oeaw.ac.at/kioes

Managing Editor:

Viktor J. Bruckman

Layout: Karin Windsteig

Cover photo credit: Fotofolia

Editorial office:

Commission for Interdisciplinary Ecological Studies, OeAW, Dr. Ignaz Seipel-Platz 2, 1010 Vienna E-mail: viktor.bruckman@oeaw.ac.at, +431515813200 


\section{Inhaltsverzeichnis}

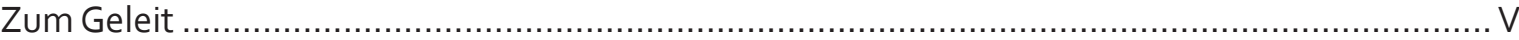

Grußworte

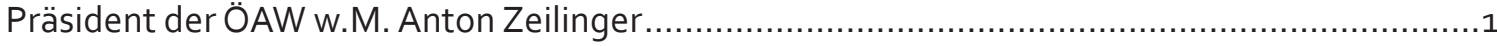

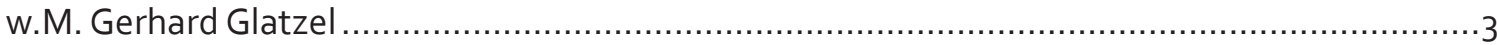

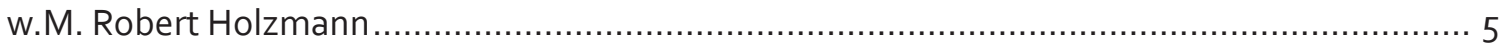

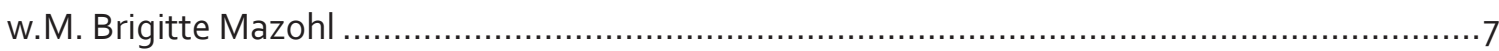

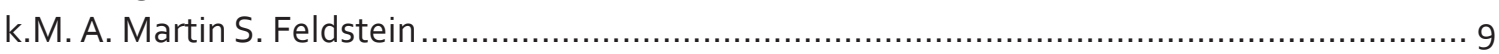

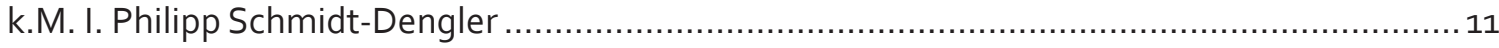

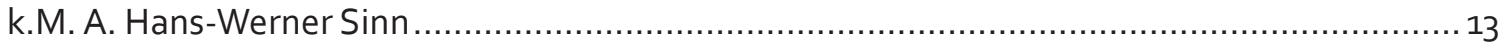

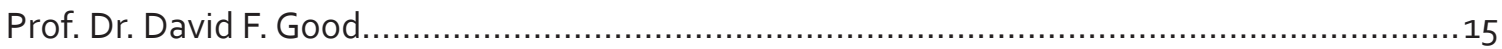

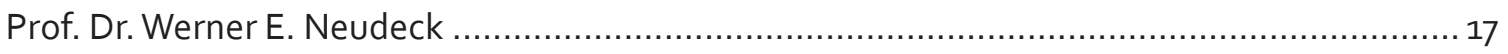

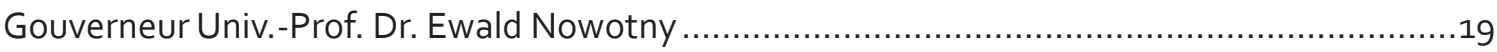

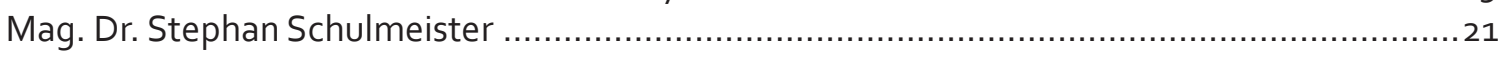

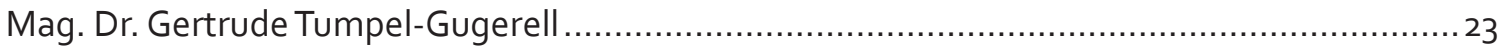

\section{ERICH STREISSLER}

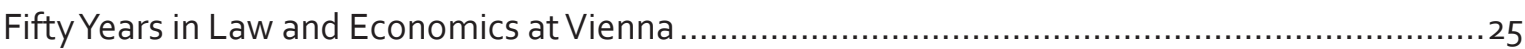

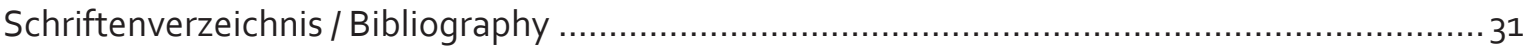

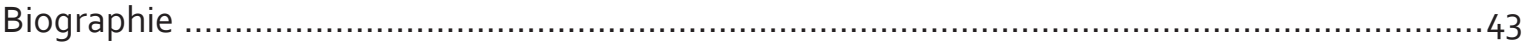

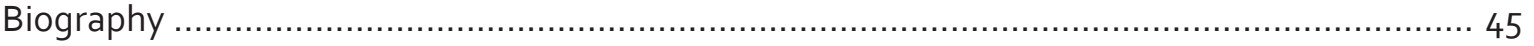





\section{Zum Geleit}

Die Kommission für Interdisziplinäre Ökologische Studien, deren Vorläufer in der Österreichischen Akademie der Wissenschaften bis ins das Jahr 1947 zurückreichen, hätte ihren Anspruch, eine klassenübergreifende Kommission der Gesamtakademie zu sein, kaum so gut erfüllen können, wenn w.M. Erich Streissler ihr nicht einen beträchtlichen Teil seiner Aufmerksamkeit und Energie gepaart mit hoher Empathie gewidmet hätte. Mitglieder der Kommission hatten bis 2014 über ein nicht unbeträchtliches Budget für Projekte zu entscheiden. Erich Streissler ist es zu verdanken, dass die Kommission gerade jene Projekte förderte, die eine disziplinen-übergreifende Herangehensweise erforderten und ermöglichten.

Er sorgte sich auch um die Finanzen der Kommission und machte über die Jahre sehr viele Vorschläge, wie diese zu verbessern seien. Sein Blick für Zahlen und die rasche Erfassung von deren Bedeutung hat die Kommission viele Male bei Entscheidungen unterstützt.

Er war einer der ersten, die das neue online-Publikationsmedium „KIOES Opinions“ nutzten, noch im hohen Alter dem Neuen stets aufgeschlossen. Die interdisziplinäre Diskussion auf Kommissionssitzungen bereichert er mit originellen und hoch bedeutsamen Fragen, die das Denken aller anregen.

Aus Anlass seines 85. Geburtstags, und um die 50. Wiederkehr seiner Berufung zum Universitätsprofessor zu würdigen, erscheint daher in der KIOESOpinions-Reihe, die bewusst darauf angelegt ist, ein weites Spektrum an Beiträgen zu ermöglichen, ein Schriftenverzeichnis des Jubilars. Der Anlass ist nicht mit dem Grund zu verwechseln, denn der Grund für diese Publikation liegt in der Beschaffenheit des Oeuvres von Erich Streissler. Wie er in seiner biographischen Einleitung zum Schriftenverzeichnis selbst ausführt, kommt er aufgrund seiner ökonomischen Überlegungen zu einer langfristigen Perspektive, die den Zustand der Natur - die ökologische Perspektive - einschließt. Während die globale Einkommensungleichheit nicht unterschätzt werden sollte, sind seiner Einschätzung nach Klimawandel, oder präziser, die globale Erwärmung, lebensbedrohlich. Er würdigt die vielen WissenschaftlerInnen und ExpertInnen, die sich in der Wissenschaft und darüber hinaus darum bemühen, den Klimawandel zu verlangsamen - von reversieren oder aufhalten kann ja bedauerlicherweise keine Rede mehr sein. Seine Schlussworte enden mit der Frage, ob das Rennen gegen die Zeit, gegen den Egoismus und gegen die absichtliche Kurzsichtigkeit derer, in deren Macht es stünde, Veränderungen herbeizuführen, gewonnen werden kann.

Hier erweist sich, dass in langfristiger Perspektive auch mit dem Blick des klassischen Ökonomen deutlich wird, dass eine Diskontierung des natürlichen Kapitals zu verzerrten Wahrnehmungen führt, die für die menschliche Gesellschaft bedrohlich sind. Um die nötige gesellschaftliche Transformation $\mathrm{zu}$ bewerkstelligen, braucht es zweifelsohne auch ökonomische Expertise. Die weit gefächerten Arbeiten Erich Streisslers, auf die solche Expertise aufbauen kann, sind bis zu dieser Publikation gerade aufgrund ihrer thematischen Breite nicht im Überblick verfügbar gewesen. Daher war es den Kommissionsvorsitzenden ein Anliegen, sie der Öffentlichkeit zur Verfügung zu stellen. Das erscheint uns als würdiger Grund für den vorgelegten Band.

Um auch dem Anlass zu entsprechen, haben wir zudem einige jener Personen, die mit Erich Streissler in einer oder anderer Weise in wissenschaftlichen Austauschbeziehungen standen oder stehen, gebeten, diesem Überblick über das Oeuvre Grußworte voranzustellen. Wir möchten uns bei allen, die dieser Einladung gefolgt sind, sehr herzlich dafür bedanken, dass sie dem Jubilar Zeit und Aufmerksamkeit gewidmet haben. In ihrer Gesamtheit sind die Grußworte aber nicht nur Dokumente von Erich Streisslers Wirken in persönlichen Beziehungen, sondern zeigen auch, wo überall seine Arbeiten Spuren hinterlassen haben.

Erich Streissler leidet seit Jahren an einer schweren Krankheit, die ihm hohe Lebensdisziplin und viel Energie abverlangt. Dass er trotzdem einer derer ist, die kaum jemals eine Sitzung der Kommission für Interdisziplinäre Ökologische Studien versäumen, ist für uns weiterhin eine große Bereicherung und gleichzeitig Ansporn. Wir bedanken uns bei ihm für das, was er immer wieder als „seine Pflicht“ bezeichnet: Seine aktive Anteilnahme und seine Beiträge zum Gedeihen der Kommission. Wir hoffen, die dauerhafte Wirkung seiner Arbeiten mit diesem Schriftenverzeichnis zu unterstützen. 
Wir möchten dieses Geleitwort mit einem herzlichen Dank an Erich Streisslers Frau Monika schließen. Sie hat nicht nur das Literaturverzeichnis und die Reinschrift der biographischen Skizze besorgt, sondern es

Wien, 7. Februar 2018 ist ihrer Fürsorge zu verdanken, dass Erich Streissler seine Pflichten auch im hohen Alter noch erfüllen kann. Wir wünschen ihnen beiden das Beste.

w.M. Verena Winiwarter Obfrau der KIÖS

k.M. I. Martin H. Gerzabek Stellvertretender Obmann der KIÖS 


\section{Grußworte}

Präsident der ÖAW w.M. Anton Zeilinger

w.M. Gerhard Glatzel

w.M. Robert Holzmann

w.M. Brigitte Mazohl

k.M. A. Martin S. Feldstein

k.M. I. Philipp Schmidt-Dengler

k.M. A. Hans-Werner Sinn

Prof. Dr. David F. Good

Prof. Dr. Werner E. Neudeck

Gouverneur Univ.-Prof. Dr. Ewald Nowotny

Mag. Dr. Stephan Schulmeister

Mag. Dr. Gertrude Tumpel-Gugerell 



\section{Präsident der ÖAW w.M. Anton Zeilinger}

Sehr geehrter Herr Professor Streissler, lieber Kollege!

Es ist eine seltene, und umso erfreulichere Aufgabe und Ehre, einem hochgeachteten Wissenschaftler und Kollegen nicht nur zur Vollendung des 85. Lebensjahres, sondern zugleich zum 50jährigen Berufsjubiläum gratulieren zu dürfen.

Vor 50 Jahren hat Sie Ihre Alma Mater, die Universität Wien, als Professor der Rechtsund Staatswissenschaften berufen. Nicht erst damit, aber ganz besonders seit Ihrer Berufung haben Sie Ihre Schaffenskraft in den Dienst von Wissenschaft, Forschung und Gesellschaft gestellt - in Österreich und weit darüber hinaus. Ihre im Verlauf dieser Jahrzehnte erworbenen Verdienste hier aufzählen zu wollen, erschiene mir ein verwegenes wie letztlich überflüssiges Unterfangen - das eindrucksvolle Verzeichnis Ihrer Schriften, dem diese Worte vorangehen dürfen, gibt davon ebenso Zeugnis, wie die zahlreichen hier versammelten Gratulationen von Persönlichkeiten, etablierten Kolleginnen und Kollegen, darunter ehemalige Schülerinnen und Schüler.

Mit besonderem Engagement haben Sie, sehr verehrter Herr Kollege, sich in dieser Zeit auch in die Österreichische Akademie der Wissenschaften eingebracht. Seit Ihrer Wahl zum korrespondierenden Mitglied vor über 30 Jahren und zum wirklichen Mitglied vor über 25 Jahren haben Sie unsere Akademie in zahlreichen Funktionen geprägt, als weithin geschätzter, streitbarer Kollege in den wissenschaftlichen Debatten in unseren Sitzungen, wie auch als Verfechter für die nachhaltige Verankerung der wirtschaftswissenschaftlichen Forschung in unserem Haus.

Sie haben dieses Engagement auch nach Ihrer Emeritierung fortgeführt und Ihre Expertise und Ihren einzigartigen Erfahrungsschatz eingebracht. Ganz besonders in Fragen der Wirtschafts- und Finanzkrisen und auch des Umweltschutzes - Themen also, die uns seit geraumer Zeit ganz besonders bewegen. Hierfür gilt Ihnen mein herzlichster Dank.

Ihren Einsatz bezeugen nicht zuletzt drei Bände der KIÖS-Opinions-Reihe, in der auch der vorliegende Band erscheint. Es freut mich sehr, dass es dank der Initiative der Kommission für Interdisziplinäre Ökologische Studien gelungen ist, dieses umfassende Verzeichnis vorzulegen, und so insbesondere auch künftigen Generationen von Wissenschaftlerinnen und Wissenschaftlern den Zugang zu Ihren Beiträgen zu erleichtern.

Namens des Präsidiums der Österreichischen Akademie der Wissenschaften und persönlich möchte ich Ihnen zu diesem besonderen Jubiläum herzlichst gratulieren.

Wien, im Februar 2018

Anton Zeilinger

Präsident der Österreichischen

Akademie der Wissenschaften 
w.M. Gerhard Glatzel

\section{Erich W. Streissler - unser Mann für die „dummen Fragen“}

Als ich im Jahr 2002 zum Obmann der Kommission für Interdisziplinäre Ökologische Studien (KIÖS) der Österreichischen Akademie der Wissenschaften gewählt wurde und damit die Nachfolge von Friedrich Ehrendorfer antrat, beschäftigte sich die Kommission im Wesentlichen mit der Dokumentation der Diversität der Pflanzen und Tiere in Österreich. Daneben unterstützten wir damals junge Wissenschaftlerinnen und Wissenschaftler bei der Exploration neuer Fragestellungen der Evolutions- und Biodiversitätsforschung als Hilfe für die Formulierung größerer Projekte, die beim FWF eingereicht werden konnten. Mitglieder der KIÖS waren überwiegend Biologen mit besonderem Interesse an Biodiversitätsforschung und ökologischen Fragestellungen.

Und da war noch Erich Streissler, Ökonom, Mitglied der philosophisch-historischen Klasse der Akademie und wortgewaltiger Disputant. Er war ursprünglich wohl nur als Aushängeschild der KIÖS für deren Anspruch auf umfassende Interdisziplinarität in die Kommission gewählt worden, entpuppte sich aber sehr rasch als unersetzbares und unermüdliches Mitglied. Er kam praktisch zu jeder Sitzung, hatte die Unterlagen studiert und stellte seine berüchtigten „dummen Fragen“, immer betonend, dass er kein Biologe, sondern Nationalökonom mit besonderem Interesse für Wechselkurse wäre. Seine Fragen brachten uns oft in allerhöchste Verlegenheit, weil sie Betriebsblindheiten der Biologen schonungslos ent-

Wien, 1. Februar 2018 larvten. Textbuchwissen entpuppte sich nicht selten als trügerisch, Widersprüche wurden sichtbar und der Nutzen von Projekten für Wissenschaft und Gesellschaft war nach Streisslers kritischer Analyse manchmal nicht mehr so klar, wie von den Antragstellern postuliert.

Für mich als Waldökologen besonders reizvoll war und ist es, mit Erich Streissler über dynamische Prozesse in Wäldern und in menschlichen Gesellschaften zu diskutieren: Wie schwierig es für einen Waldökologen ist, in der Natur den „typischen“ Waldbestand zu finden, der sich modellkonform entwickelt, und wie rasch ein Sturm - im wahrsten Sinn des Wortes alles über den Haufen werfen kann, oder wie unvorhergesehen eine neue Krankheit, wie beispielsweise das Eschensterben, alle Vorhersagen Lügen strafen kann. Es war immer tröstlich zu erfahren, dass der Ökonom, der vergangene Wechselkursänderungen von Währungen recht gut erklären kann, deren zukünftige Entwicklung auch nicht verlässlich vorherzusagen vermag.

Ich möchte den 85. Geburtstag von Erich Streissler zum Anlass nehmen, mich bei ihm für die langjährige Mitarbeit und Kooperation in der KIÖS zu bedanken. Ich habe viel gelernt und profitiert, obwohl ich eingestehen muss, dass seine Fragen auch mich manchmal aus der Fassung gebracht haben. Dem Jubilar und seinem kritischen Geist noch viele interessante und stimulierende Jahre.

Gerhard Glatzel

Obmann der KIÖS von 2002 bis 2016 


\section{Ein dreifach Hoch dem Lehrer und Mentor, Ökonomen und Akademiemitglied Professor Streissler}

Die Matura und die Familie in Graz verführten mich dazu, das Volkswirtschaftsstudium an der erst jüngst eingerichteten Studienrichtung der Sozial- und Wirtschaftswissenschaften an der damaligen Rechts- und Staatswissenschaftlichen Fakultät der Karl-Franzens Universität Graz aufzunehmen. Die juristische Ausbildung war sehr gut, die ökonomische durch viel Selbststudium gekennzeichnet, doch man hörte durch Kommilitonen von einem Volkswirtschaftsinstitut in Wien, wo wirklich gute Lehre gemacht würde und es einen aus Deutschland rückimportierten Starprofessor gäbe. Diese Informationen verdichteten sich, als ein dortiger Dozent einen Ruf nach Graz erhielt und nun erstmalig Volkswirtschaftslehre auf modernem Niveau unterrichtete. Bei diesem Professor wurde ich Assistent und war daher bestens über Wien informiert. Nach zwei Jahren folgte ich ihm an das berühmte Wiener Institut, als Prof. Bös einen Rückruf erhielt. Als Dissertant und nunmehriges Institutsmitglied stand ich naturgemäß auch im Blickwinkel der grauen Eminenz dieser Institution, und er folgte genau meinen Arbeiten; die von mir gewählten Themen waren ungewöhnlich für das Institut. Mein Dissertationsthema „Simulationsanalysen zur österreichischen Pensionsversicherung“ verleitete ihn zur Frage an meinen damaligen Chef: „Was der Holzmann da macht, ist das Wissenschaft?“ Die positiven externen Reaktionen auf meine Arbeit, (die Erste dieser Art in Österreich und eine der Ersten dazu auf der Welt) begannen ihn zu überzeugen. Dies verstärkte sich, als im Rahmen eines von Prof. Streissler organisierten Wiener Seminars von Prof. Martin Feldstein (dem damaligen Star der amerikanischen Ökonomen) ich dessen Ergebnisse für die österreichische Sozialversicherung replizierte und verfeinerte (Marty, den ich später vielfach international traf, konnte sich an das Seminar und die Inhalte noch genau erinnern). Letztlich war es meine Habilitation zum Thema „Intertemporale Verteilungsanalyse", für welche er naturgemäß der Hauptgutachter war, da Prof. Bös nach Bonn weitergezogen war. Meine Habilitation machte ihn zum Fan der Verknüpfung von Theorie, Empirie und Computersimulation vor dem Hintergrund von relevanten wirtschafts- politischen Fragestellungen. Dass dafür ab und zu notwendige inhaltliche und methodische Reiben hat uns jedoch niemals getrennt, sondern vielmehr stark angenähert. Diese Beziehung hielt auch an während meiner Auslandsprofessur und Tätigkeiten in internationalen Organisationen.

Neben seinen direkten und indirekten Beiträgen zu meiner persönlichen beruflichen Entwicklung, für welche ich ihm sehr dankbar bin, hat sich Prof. Streissler unschätzbare Verdienste um die Wiedererweckung der Lehre und Forschung der Volkswirtschaftslehre am Institut und in Österreich gemacht. Durch Vertreibung oder Befreiung von Mitläufern und Unterstützern unterschiedlichster Systeme war Österreich am Beginn der 60er Jahre eine weitgehende volkswirtschaftliche Steppe. Seinem Rückruf und seiner internationalen Ausrichtung, seinem Standard und seinem Leitbild ist es wohl zu verdanken, dass sich innerhalb von weniger als zwei Jahrzehnten die Ausbildung wesentlich verbessert hat und Absolventen und Dozenten des Instituts vielfach begannen, die Lehrstühle an anderen Universitäten in Österreich zu besetzen. Diese sehr gute Ausbildungsbasis wurde durch die Errichtung des Institutes für Höhere Studien (IHS) und das dortige PostgraduateStudium und seine theoretisch-empirische Vertiefung noch verstärkt. Wesentlich war dabei auch, dass sich damals Ökonomen an österreichischen Universitäten nicht zu schade waren, zu österreichischen Themen relevant und pointiert Stellung zu nehmen. Prof. Streissler gehörte naturgemäß dazu. Dabei prägt ihn sein ökonomisches Denken, das gekennzeichnet ist von einer Verbindung von Jurisprudenz und Ökonomie, Theoriegeschichte und moderner Theorie, ökonometrischem Wissen und wirtschaftspolitischen Fragestellungen.

Diese Verbindung verschiedenster wissenschaftlicher Disziplinen mag wahrscheinlich auch einer der Gründe dafür gewesen sein, warum er schon in sehr, sehr jungen Jahren zum Akademiemitglied gewählt wurde. Ich kenne nur wenige Hintergrundelemente aus dieser Zeit durch vergangene Erzählungen von Angehörigen des anderen und nunmehr verbliche- 
nen Ökonomenstammes an der Akademie. Trotz $\mathrm{Pu}$ blikation meiner ersten beiden Bücher im Verlag der Akademie (darunter meine Dissertation) setzt meine Erfahrung mit der Akademie und Prof. Streissler erst wieder nach meiner Rückkehr nach Österreich vor sieben Jahren ein. Seiner Einladung zur Teilnahme am Ausschuss für „Internationale Finanzierung“ bin ich gerne gefolgt, weil ich als ehemaliger Mitarbeiter des Internationalen Währungsfonds und der Weltbank mit dem Thema eng verbunden war und bin, aber auch um als Heimkehrer das Denken der

23. Februar 2018 örtlichen Ökonomen und das Funktionieren der Akademie kennen zu lernen. Wie auch später als Akademiemitglied, für das er gemeinsam mit Gerhart Bruckmann wohl auch Verantwortung trägt, habe ich dabei den Einsatz und das Wissen von Erich kennen und sehr schätzen gelernt: als Themensetzer, als historische Fundgrube, als Geschäftsordnungsspezialisten oder auch einfach als Menschen. Ich hoffe, dass ihm noch viele Jahre im Rahmen der Akademie vergönnt sein werden, zu deren treuesten und maßgeblichsten Mitgliedern er wohl zählt.

Robert Holzmann

vorm. Mitglied des Direktoriums der Weltbank 
w.M. Brigitte Mazohl

Sehr geehrter Herr Jubilar, lieber Herr Streissler,

als vormalige Klassenpräsidentin der philosophisch-historischen Klasse, der Klasse also, der Sie seit dem Jahr 1986 angehören, darf ich Ihnen zum großen Ehrentag, den Sie am 8. April begehen, meine herzlichsten Glückwünsche überbringen.

Wir kennen uns persönlich erst seit fünfzehn Jahren, aber natürlich sind mir Ihr Name und Ihr wissenschaftlicher Ruf schon lange zuvor ein Begriff gewesen. Es ist mir also eine Freude, zugleich mit Ihrem Geburtstag auf diese Weise auch das Jubiläum meiner fünfzehnjährigen Bekanntschaft mit Ihnen feiern zu dürfen - so lange ist es nämlich her, dass Sie mir als frisch gewähltem korrespondierendem Mitglied unserer Akademie gratulierten und dabei eine Formulierung gebrauchten, die heute eher selten geworden ist: „Küss' die Hand, gnädige Frau!“. Damals bereits habe ich Ihre chevalereske und formvollendete Art im Umgang mit mir (und vermutlich auch mit den anderen - bekanntlich nicht so zahlreichen - Damen an der Akademie) bewundert, und nachdem ich im Jahr 2013 zur Klassenpräsidentin gewählt wurde, zählten Sie zu denjenigen, die mich bei jeder Sitzung auf das Freundlichste begrüßten. Sie vermittelten dabei stets den Eindruck, als freuten Sie sich, in der Sitzung zugegen zu sein, und Sie haben sich stets auch besonders engagiert, temperamentvoll und klug sowohl zu den wissenschaftlichen als auch zu den organisatorischen Fragen zu Wort gemeldet. Seit ich erfahren hatte, dass Sie bereits vor Jahren dafür eingetreten sind, das gesetzliche Pensionsalter auf 80 Jahre anzuheben, konnte ich Ihren unermüdlichen Einsatz noch sehr viel besser verstehen. Ich fühle mich Ihnen in dieser Frage sehr verbunden, denn ich denke auch, dass - jedenfalls für Wissenschaftler/innen - die Vita activa nicht einfach auf Knopfdruck, oder weil eine gesetzliche Vorgabe es so will, auf eine reine Vita contemplativa umgestellt werden kann - im Idealfall, wie in Ihrem Falle, hat der Wissenschaftler/die Wissenschaftlerin wohl auch ohne gesetzliche Vorgaben beides bereits vorher zu verbinden gewusst und sehr gut selbst zu entscheiden gelernt, welche Seite der Waagschale wann mehr Gewicht bekommen soll. So haben Sie Ihrerseits diese sozialpolitische Forderung auf eindrucksvolle Weise erfüllt und sind als akademischer Lehrer ebenso wie als Wissenschaftler bis zu Ihrem 80. Geburtstag unermüdlich tätig geblieben; erst in den letzten Jahren hat Ihre schwere Krankheit Sie veranlasst, sich mehr der kontemplativen Seite zuzuwenden. Dass Sie in Zukunft auch diese Seite trotz aller Einschränkungen nach Kräften genießen können, das wünsche Ich Ihnen von Herzen.

Wenn wir von diesen späten Jahren kurz zurückblicken auf Ihre wissenschaftlichen Anfänge, dann gilt es einen ganz besonderen Karriereverlauf hervorzuheben, der wohl in der akademischen Welt als einzigartig zu bezeichnen ist. Sie erwähnten gelegentlich gerne ihr jugendliches Alter, mit dem Sie - 1962 - als ordentlicher Professor für Statistik und Ökonometrie nach Freiburg i.Br. berufen wurden. Tatsächlich waren Sie damals erst außerordentliche 29 Jahre jung, nachdem Sie sich wenige Jahre zuvor als 26jähriger (!) bereits (für Volkswirtschaftslehre) habilitiert hatten. Dass Sie aber auch Ihr Studium in der Rekordzeit von vier Jahren absolviert haben und als 22jähriger bereits zum Doktor juris promoviert wurden, haben Sie uns bisher vorenthalten. Und dass auf einen derart rasanten Aufstieg in die höchsten akademischen Ränge ein Forscherleben von höchstem nationalem und internationalem Renommee folgen würde, dessen Le- 
bensleistung auch mit dem hier vorliegenden Band nochmals gewürdigt werden soll, versteht sich von selbst.

Lassen Sie mich aber - über die offenbar von uns beiden geschätzte Galanterie und die Freude am Wirken über das vorgeschriebene Emeritierungsalter hinaus - einen weiteren Aspekt ansprechen, der uns trotz der scheinbar so verschiedenen wissenschaftlichen Disziplinen, denen wir angehören, verbindet. Sie sind Nationalökonom und als solcher natürlich auch Historiker. Sie haben dieses Fach - neben Ihren Hauptfächern Jura, Ökonomie, Mathematik und Statistik - nicht nur studiert, sondern im Zusammenhang mit (volks)wirtschaftlichen Entwicklungen an den verschiedenen Universitäten (in Freiburg, Wien, Oxford, Stanford) auch gelehrt. Sie haben darüber hinaus aber auch - gemeinsam mit Ihrer Frau Monika Streissler - die Lehrunterlagen (Lectures), die Carl Menger als Privatlehrer von Kronprinz Rudolf für seinen Schüler verfasst hat, bearbeitet, herausgegeben und ins Englische übersetzt - und hier zeigt sich eine enge Verbindung auch zu meinen wissenschaftlichen Interessen. Denn ich habe meinerseits in meiner Lehrtätigkeit zur Österreichischen Geschichte immer wieder mit Gewinn auf das sogenannte Kronprinzen-Werk Erzherzog Rudolfs zurückgegriffen, dessen volkswirtschaftliche Teile ja von seinem prominenten Lehrer maßgeblich geprägt worden sind. Und über Menger führt der Weg natürlich auch zu Lorenz von Stein, den Habilitationsvater Mengers, den „mein“ Unterrichtsminister Leo von Thun-Hohenstein als Professor für Politische Ökonomie im Jahr 1855 nach Wien berufen hat. Thun, dessen Korrespondenz aus der Ministerzeit, wie Sie ja wissen, von mir gemeinsam mit jüngeren Kollegen als online-Edition, aber auch als gedruckte Auswahledition herausgebracht wird, hat diese Berufung des Protestanten Stein gegen den massiven Widerstand katholischer Kreise durchgesetzt - und damit für die künftige Entwicklung Ihres Faches entscheidende Schritte gesetzt. Lorenz von Stein war im Übrigen auch einer der ersten Nationalökonomen, der den volkswirtschaftlichen Nutzen von unbezahlter „Frauenarbeit" erkannt und sogar errechnet hat - ein Pionier also wie sein nicht minder bedeutender Schüler Menger, dessen Lehrstuhl dann auch Sie, verehrter Herr Streissler, über viele Jahre, von 1968 bis 2001, so erfolgreich innehatten.

Mit diesen wenigen Worten der Wertschätzung darf ich Ihnen zu Ihrem halbrunden Geburtstag und mir zum fünfzehnten Jahrestag unserer Bekanntschaft von Herzen gratulieren!

19. Februar 2018

Brigitte Mazohl

Universität Innsbruck 
k.M. A. Martin S. Feldstein

\section{HARVARD UNIVERSITY}

Martin S. Feldstein
George F. Baker
Professor of Economics
NBER

1050 Massachusetts Avenue

Cambridge, Massachusetts 02138

PHONE: (617) 868-3905

FAX: (617) 613-1298

Dear Erich:

I am pleased to join your other colleagues and students in greeting you on the occasion of your $85^{\text {th }}$ birthday and the $50^{\text {th }}$ anniversary of your appointment as a professor at the University of Vienna.

I remember very clearly how we met in Oxford in the 1961-62 academic year. I had recently graduated from Harvard and came to Oxford as a Fulbright Fellow. We met in the graduate seminar on macroeconomics that met weekly. Monica also attended the seminar.

I was 21 years old and you were 28 years old. I had not had any previous experience with graduate students at Harvard and the other students in the seminar were also inexperienced and not at all professional.

You were a wise and mature presence in the seminar. Although I cannot remember any specific discussions, I do remember that you represented a serious professional voice as someone who knew much more economics than the rest of us.

You have been my link to Vienna in the years that followed. Twenty years later in March 1981 you arranged for me to come to Vienna as the Joseph Schumpeter Professor. In addition to giving a lecture in that capacity I also gave a series of presentations at your seminar. (By coincidence, I now hold the chair at Harvard that was held by Schumpeter when he was a member of my department.)

You and Monica were very generous hosts when my wife, Kate, and I were in Vienna. I remember walking in the woods and eating in a very good restaurant that you liked. You even allowed your son to act as a baby sitter for our two daughters!

Fifteen years later, in 1996, you arranged for my election as a foreign member of the Austrian Academy of Sciences, reinforcing my link to Austria.

My wife and I have returned to Vienna in recent years and had the pleasure of seeing you and Monica for dinner and discussions.

I have just completed fifty years of teaching at Harvard. But you still remain the wise senior professor that you were when we met in Oxford. 


\section{k.M. I. Philipp Schmidt-Dengler}

„Unter den jungen Ökonomen beeindruckte mich besonders Professor Erich Streissler, Ordinarius für Volkswirtschaftslehre, Ökonometrie und Wirtschaftsgeschichte an der Universität Wien [....]“ schrieb Bruno Kreisky im zweiten Teil seiner Memoiren „Im Strom der Politik“. Auch viele Jahre später war es Streissler, der auf uns Studierende den größten Eindruck machte. Ehrfürchtig fragte man einen Kollegen oder eine Kollegin höheren Semesters: „Warst Du beim Streissler?"

Während die meisten, auch fortgeschrittenen, Lehrveranstaltungen sich um das Einüben von Methoden und Rechnen von Beispielen drehten, ging es bei einem Streissler-Seminar darum, neuere Forschungsartikel zu lesen und zu kritisieren. Das Interesse für genuine ökonomische Fragestellungen war bei Studierenden der Ökonomie stärker ausgeprägt, als ihr Wunsch, nichtlineare Gleichungssysteme möglichst elegant zu lösen. Auch der Autor dieser Zeilen sieht die Vorteile durchstrukturierter Studienprogramme, in denen Studierende zu fortgeschrittenen Lehrveranstaltungen nur zugelassen werden, wenn sie sich bereits die notwendigen Grundlagen in einführenden Kursen angeeignet haben. Doch wann beherrscht man wirklich alle Grundlagen, um aktuelle Forschungsarbeiten zu verstehen? Vermutlich nie, sonst gäbe es in den Forschungspapieren ja kaum Neues zu finden. Streissler traute uns Studierenden mehr zu als andere, und forderte uns damit heraus.

Um eine Lehrveranstaltung bei Streissler zu besuchen, bedurfte es daher einer gewissen Risikobereitschaft. Bei ihm waren die Studierenden selbst dafür verantwortlich, sich die Grundlagen zu erarbeiten, um bei der Diskussion einer neueren Arbeit nicht aufs Glatteis zu gelangen. Ein Seminar bei Streissler

Wien, 22. Februar 2018 war das Gegenteil eines heute oft geforderten intellektuellen „safe space“. Nichts und niemand war sicher. Es gab in der Diskussion keine Tabus. Auch Arbeiten großer Ökonomen (meist Männer) wurden zerlegt, Widersprüche aufgedeckt. Und natürlich gab es auch keine "trigger warnings“: Streissler schoß schnell. Mit seiner unvergleichlichen Kenntnis der Literatur und empirischer Zusammenhänge, seinem historischen Wissen und nicht zuletzt mit seinem Witz konnte er auch besonders scharf schießen. In der Debatte nahm er bewusst Positionen ein, um uns zu zwingen, unsere Gedanken zu Ende zu bringen und exakt zu formulieren. Es war Universität im besten Sinne.

Streissler war auch nie verlegen, sein Wissen und seine Analysen in die öffentliche wirtschaftspolitische Debatte einzubringen. Das, was die Universität heute etwas großspurig als ihre „third mission“ bezeichnet, war für ihn eine Selbstverständlichkeit. Er beherrschte sie wie kein anderer. Seine Zeitungskommentare oder seine Auftritte in TV-Diskussionen führten unter Studierenden oft zu Debatten bis in die frühen Morgenstunden.

Streissler zeigte sich von Bruno Kreisky's ökonomischem Verständnis wenig beeindruckt. Und wie Kreisky's Bewunderung wird auch die von uns Studierenden eine eher einseitige Angelegenheit gewesen sein. Aber wir durften vieles andere mitnehmen. Egal ob das Thema Geldtheorie, Wechselkurse oder Pensionspolitik war. Wir lernten, Arbeiten auf ihre logische Konsistenz und auf ihren empirischen Gehalt zu prüfen. Wir lernten, alles zu hinterfragen: Die Annahmen, die Methoden, die Datengrundlage, aber immer auch die eigene Position in der Debatte.

Philipp Schmidt-Dengler

Universität Wien 


\section{k.M. A. Hans-Werner Sinn}

\section{Erich Streissler}

Erich Streissler ist der bedeutendste österreichische Nationalökonom seiner Generation. Wie kein anderer hat er die institutionelle und geistige Entwicklung des Faches in seinem Heimatland geprägt und strahlte mit seinem Wissen weit darüber hinaus.

Nachdem Streissler Jura studiert und dann in diesem Fach promoviert hatte, wandte er sich der Statistik und der Volkswirtschaftslehre zu. Schon im jungen Alter von 29 Jahren hatte er ein Oeuvre und eine Expertise vorzuweisen, die ihm ein Ordinariat für Statistik und Ökonometrie in Freiburg einbrachten. Zahlreiche Aufenthalte in angelsächsischen Ländern hatten ihn schon zu diesem Zeitpunkt zu einem international beachteten Forscher gemacht.

Sechs Jahre später kehrte er nach Wien zurück, wo er der Rechts- und Staatswirtschaftlichen Fakultät beitrat und eine intensive Vorlesungstätigkeit im Bereich der Jurisprudenz begann. Im Zuge der Neuordnung der Universität wurde er ab 1975 Mitglied der Fakultät für Sozial- und Wirtschaftswissenschaften, was ihm zupass kam, weil sich seine Neigungen ohnehin dorthin richteten.

Erich Streissler ist ein Universalgelehrter, der wie kein anderer die Kenntnisse der Jura, der Statistik und der mathematischen Wirtschaftstheorie zu verbinden weiß und sich zudem noch als Fachmann in der volkswirtschaftlichen Dogmengeschichte einen Namen gemacht hat. Als Wissenschaftler ruht er auf dem breiten Fundament der Österreichischen Schule, doch ist er ein kenntnisreicher neoklassischer Ökonom, der zugleich maßgebliche Beiträge zur Geldund Zinstheorie geleistet hat. Dabei haben ihn die internationalen Probleme der Wirtschaftstätigkeit stets besonders beschäftigt, so zum Beispiel die Frage, welche Einflussfaktoren die Leistungs- und Kapitalverkehrsbilanz erklären. Seine stets auf Englisch gehaltenen Vorlesungen waren legendär, insbesondere seine Vorlesung International Economics, die mit ihrer geschickten Verbindung von Theorie, Empirie, historischen Erfahrungen und Dogmengeschichte Kultstatus erreichte. Mit einfachsten Mitteln gelang es ihm, tiefschürfende theoretische Erkenntnisse zu vermitteln und dabei ein breites Spektrum auch moderner Literatur darzulegen.

Ich selbst bin auf ihn als Student durch seine vielen Diskussionsbeiträge bei den Jahrestagungen des Vereins für Socialpolitik aufmerksam geworden, die damals noch wörtlich protokolliert wurden. Seine direkte und unverblümte Ausdrucksweise hat mich stets beeindruckt. Wenn er das „Schlittenfahren auf neoklassischen Isoquanten “ brandmarkte oder die Argumentation eines Keynesianers genüsslich auseinandernahm, imponierte mir das sehr.

Im Jahr 1972 durfte ich als frischgebackener Universitätsassistent an der Jahrestagung des Vereins für Socialpolitik zum Thema „Macht oder Ökonomisches Gesetz" teilnehmen. Ich werde nie vergessen, wie er in dem total überfüllten Hörsaal ein nicht eingeplantes, flammendes Korreferat zu Winfried Vogt hielt, dessen linke Thesen ihm überhaupt nicht gefielen. Er schloss sein Referat mit der Bemerkung „Gott schütze uns vor der Macht der Vögte“ und verließ, sichtlich erregt, den Raum.

Nein, Erich Streissler hielt überhaupt nichts von linken Wunschträumen und vertraute der Macht der Märkte. Das hat er auch später immer wieder unter Beweis gestellt. So hat er als einer der ersten erkannt, dass die staatlich gelenkte deutsche Vereinigung schnurstracks in eine Transferunion und zu einer dauerhaften Lähmung der Wirtschaft führen würde. Und zum Thema Euro hatte er von Anfang an keine Illusionen. Seine pessimistischen Prognosen zur Gefahr der Vergemeinschaftung der Schulden im Eurosystem haben sich bewahrheitet.

In den letzten Jahren hat sich Streissler viel mit dogmenhistorischen Themen beschäftigt. So hat er die großartigen Leistungen von Wilhelm Roscher, der schon im 19. Jahrhundert die keynesianische Theorie der Absatzkrisen vorwegnahm, für die Nachwelt ins richtige Licht gesetzt. Auch hat er der Fachöffentlichkeit in Erinnerung gerufen, dass schon 1832 der in München lehrende Friedrich Benedikt Wilhelm von Herrmann die mit der Absatzmenge steigende 
Grenzkostenkurve, die die Basis der neoklassischen Wirtschaftstheorie wurde, hergeleitet hat.

Was wäre Erich Streissler ohne seine Frau Monika Streissler? Sie hat seine Manuskripte redigiert, mit ihm an Büchern gearbeitet und trat vielfach mit ihm und für ihn als Übersetzer wichtiger Werke der ökonomischen Klassik auf. Die beiden sind ein wissenschaftliches Traumpaar, von denen es nicht viele in unserer Disziplin gibt. Jede verdiente Ehrung für Erich Streissler ist zugleich auch eine Ehrung für sie.

Hans-Werner Sinn

Universität München 
Prof. Dr. David F. Good

\section{Reflections on Professor Erich Streissler}

I am deeply grateful to KIOES for inviting me to join with others in honoring Erich Streissler in this celebratory year of his $85^{\text {th }}$ birthday and the $50^{\text {th }}$ anniversary of his appointment as Professor at the University of Vienna.

I have known Erich since 1980 in the multiple roles he has played so brilliantly in his stellar academic career. Other than members of my family, no person has had a greater impact on my professional career than Erich. He came into my academic life early on and in important ways, so I honor him with a memoir that captures the essence of his impact on me.

Back in 1979, early in my career, the well-known Austrian economic historian Eduard März suggested that I consider lecturing at the University of Vienna on my research specialty, the economic history of the Habsburg Empire in the century prior to its dismantling in the Paris Peace Treaties of 1919. I agreed to pursue his idea but then we struggled with what that meant in practice.

One afternoon, while deep in thought in my office at Temple University, the phone rang. Erich was calling me long distance from Vienna. With patience and grace, he quietly assured me that my visiting professorship in the Economics Faculty at the University of Vienna was on track and I was free to structure my lectures however I wished. With that call, I experienced one of Erich's many skills: the art of diplomacy in resolving difficult situations.

Through the 1980s, Rosemary and I returned regularly to Austria, thanks to Erich's gracious invitations. Very early on I appreciated the breadth and depth of his mind as an economist. He seemed equally at home in all the subfields of the "discipline", from high theory to the quantitative and more policy-oriented wings, especially the new field of environmental economics.

His true passion, though, seemed to be the history of economic thought; how intellectuals in the past developed economics into the distinct branch of knowledge it is today. We had many stimulating conversations about this, especially regarding the late $19^{\text {th }}$ century icons of the Austrian School of Economics pioneered by Carl Menger, Eugen Böhm von Bawerk, Friedrich von Wieser and their early $20^{\text {th }}$ century followers.

Thankfully Erich's initial invitation led to a string of immensely valuable intellectual experiences. As a field of intellectual inquiry, economic history straddles precariously its two parent disciplines, economics and history, which differ dramatically in focus, methodology, and intellectual sensibilities.

I welcomed teaching economics students because my training as an economic historian in the United States occurred well after the post-World War II migration of economic history from history departments into economics departments. The shift gave birth to the "New Economic History", which advocated using economic theory and quantitative methods to frame the analysis and the substance of their storytelling.

Erich's invitations were unique because in Austria as in the rest of Europe, teaching and research in economic history had remained a special subfield within humanities faculties. For Erich I taught advanced seminars much the way I did at home - using the tools of economics to study the history of economic development in the United States, Western Europe, and the pre-1914 Habsburg Empire.

In all of these visits, Erich played a critical mentoring role for me as a younger colleague. He did so patiently with gentle words of encouragement and suggestions that buoyed my confidence. More importantly, he strengthened my resolve to transform my narrowly focused $\mathrm{PhD}$ dissertation and broader lecture notes into my book, The Economic Rise of the Habsburg Empire 1750-1914 (University of California Press, 1984).

From the very beginning Rosemary and I became friends with Erich's, gracious, intellectually vibrant wife, Monika, and their two charming, brighteyed young daughters, Agnes and Anna. Thanks to Monika's masterful cooking skills, we enjoyed many elegantly prepared dinners spiced with stimulating, 
conversations about family, Austria, and the wider world.

Over time my friendship with Monika turned professional as well when she offered to translate my book into German, an offer I knew would dramatically enlarge its readership. Monika convinced the highly regarded German-language publisher, Böhlau Verlag, to do a translation, which she carried out splendidly while correcting substantive errors along the way.

On the heels of the publication, Erich arranged for me to receive the title "Honorary Professor of Economic History" at the University of Vienna. I was, of course, deeply flattered. On the occasion of my official installation, I gave a talk in German on the main themes of my book, thanks to Monika's expert translation from my English version.

When I reached mid-career at Philadelphia's Temple University in the mid-1980s, I had the urge to move from my economics department into a department of history at a new institution. I routinely scanned job openings and explored several options with no luck until 1988. I spotted a listing that seemed perfect for me - a position at the University of Minnesota as Director of its Center for Austrian Studies with tenure in the Department of History.

The Center had been created in 1977 with a generous gift of $\$ 1$ million from the Austrian people in celebration of America's bicentennial anniversary. I applied immediately and asked Erich if he would write a letter of recommendation. He agreed and wrote what I am sure was a strong and enthusiastic letter that played an important role in the decision to hire me.

Sometime later, Erich visited us in Philadelphia as part of an extended trip to the United States. On a long walk, I expressed excitement but also concerns about whether I was up to the task of moving the Center to a new level. Ever the thoughtful mentor, Erich patiently put me at ease and gave me confidence. I recalled that moment whenever I was in doubt.

Our trips to Austria naturally became more frequent during the years I served as CAS director. Near the end of my term, I had the high privilege of assisting Monika in her English translation of Carl Menger's Lectures to Crown Prince Rudolf of Austria, edited by Erich and Monika.

After my term ended, Rosemary and I continued to travel regularly to Europe for academic or other reasons. On most of these trips we found our way to Vienna and reunited with Erich and his family. These were delightful occasions for catching up on family matters, reminiscing about old times, and solving the problems of the world.

From the very beginning of our friendship, we've continued to exchange lengthy Christmas greetings with detailed family updates every year. I am deeply grateful for this special opportunity to join with other friends of Erich in reflecting on my memories of him and the special place he and his family have in our hearts. I hope our collective reflections will show him what an inspiration he has been to so many people.

David F. Good

University of Minnesota 
Prof. Dr. Werner E. Neudeck

Als ehemaliger Student, langjähriger Assistent, Kollege und - wenn ich es so formulieren darf - Freund und steter Bewunderer von Erich Streißler ist es mir eine besondere Freude und Ehre, einige Zeilen zu dieser Festpublikation beitragen zu können. Ich erinnere mich noch an unsere erste Begegnung in der (fakultativen) Einführungsvorlesung in die Volkswirtschaftslehre, die mir von einem älteren Studienkollegen und späteren Spitzenmanager als die „beste des ganzen Studiums" empfohlen worden war. In den seither vergangenen 45 Jahren durfte ich den Jubilar doch recht gut kennenlernen und ich kann wohl sagen, daß mich außerhalb meiner engsten Familie kaum ein Mensch so nachhaltig geprägt hat wie er. In sehr vielen Dingen war und ist er mir ein - freilich nie erreichbares - Vorbild.

Es muß hier nicht betont werden, daß Erich Streißler wohl völlig unbestritten der bedeutendste und international bekannteste österreichische Ökonom seiner Generation ist. Das vorliegende Schriftenverzeichnis gibt ein beredtes Zeugnis seiner wissenschaftlichen Leistung. Erich Streißler hat seine theoretischen Erkenntnisse aber auch immer auf konkrete wirtschaftspolitische Fragen angewandt. Er nahm seine Tätigkeit im Österreichischen Institut für Wirtschaftsforschung oder als Börserat besonders ernst und wurde als „Public Intellectual“ einer breiten Öffentlichkeit über Zeitungsbeiträge und Rundfunk-Interviews bekannt. Auch Politiker von rechts und links und andere wirtschaftspolitische Entscheidungsträger orientierten sich an seiner Meinung, auch wenn sie ausnahmsweise nicht seine Studenten waren. So zitierte ihn Bruno Kreisky in seinen Memoiren häufiger und positiver als manchen Parteifreund.

Bis zu seinem 80. Geburtstag hielt Professor Streißler gut besuchte bis überfüllte Lehrveranstaltungen. Als begnadeter Vortragender und Lehrer begeisterte er Generationen von Juristen, Volkswirten, und später auch Betriebswirten. Keiner seiner Hörer wird die anspruchsvolle, aber spannende Präsentation, die wohlgesetzten Worte, oder die markante Sprachmelodie vergessen. Legendär waren auch die 3-tägigen Fortgeschrittenen-Seminare im (meist verschneiten) Stift Heiligenkreuz, in die ich mich als Student nie gewagt hätte, die ich aber als Assistent viele Jahre lang mitbetreuen durfte. Kaum eine andere Lehrveranstaltung meiner akademischen Laufbahn war mit ähnlich großen Anstrengungen und einem ähnlich großen Lernerfolg für die Teilnehmer verbunden. Das inoffizielle Motto dieses Seminars entsprach einer alten Forderung der 68erStudentengeneration: „High sein, frei sein, Terror muß dabei sein!“

Beeindruckend ist sicher auch die Originalität der Gedanken unseres Jubilars. Jeder noch so kleine Vortrag oder Überblicksartikel enthält Überlegungen, die auch für den Experten neu und stimulierend sind. Die offenkundige Brillanz ist aber gepaart mit einer fast protestantischen Arbeitsethik und großer Gewissenhaftigkeit. Obwohl Erich Streißler in freier Rede unübertroffen war, wurde jede Vorlesung und jeder Vortrag akribisch vorbereitet und zuerst handschriftlich verfasst (oft inklusive Minutenangaben zu den Absätzen). Als junger Assistent vermeinte ich, das Universitäts-Hauptgebäude nicht vor meinem „Chef" verlassen zu sollen (was freilich niemals gefordert worden war). So habe ich viele Abende an der Universität verbracht, was meiner eigenen Arbeit sicher zuträglich war und regelmäßig mit einem längeren spät-abendlichen Gespräch belohnt wurde.

Erich Streißler beeindruckte mich zudem mit seinem unglaublich breiten Allgemeinwissen und seinem wahrhaft interdisziplinären Ansatz. In vielen Gesprächen mit ihm konnte ich nicht nur fast alles über Ökonomie, Wirtschaftsgeschichte oder Statistik erfahren, sondern auch sehr vieles über Politik, allgemeine Geschichte, Botanik, Zoologie, Psychologie, Theologie, Literatur, bildende Kunst und vieles mehr. Die Erfahrung dieses stets wachsenden Wissensschatzes in einer Person hat mich jedenfalls unter anderem (ein wenig) Bescheidenheit gelehrt.

Erich Streißler ist einer der - immer seltener werdenden - großen "Charaktere" des akademischen Universums. Unzählige Anekdoten ranken sich um seine Person. Zu ihrer Verbreitung (und vielleicht Veränderung) konnte ich selbst ein wenig beitragen.

In feines (englisches?) Tuch gehüllt ist Erich Streißler immer durch seine elegante äußere Erscheinung aufgefallen. Noch viel wichtiger war und ist ihm aber zweifellos die innerliche Welt des Geistes und der Seele. Der gleichsam dazwischenliegenden Welt 
der „Körperlichkeit“ maß er hingegen relativ wenig Bedeutung zu. Dies - und sein fester Glaube - mag ihm helfen, die körperlichen Beschwerlichkeiten des Alters besser zu ertragen.

Wien, 22. Februar 2018
Lieber Erich! Zu guter Letzt möchte ich Dir für all Deine "guten Werke“ und für die schönen und lehrreichen gemeinsamen Jahre danken und Dir herzlich zum Jubiläum gratulieren. Ad multos annos feliciter!

\author{
Werner Neudeck \\ Diplomatische Akademie Wien
}


Gouverneur Univ.-Prof. Dr. Ewald Nowotny

\section{Erich W. Streissler zu Ehren}

Der 85. Geburtstag Erich Streisslers ist eine schöne Gelegenheit, einen Mann zu ehren, der über einen langen Zeitraum die akademische Wirtschaftsforschung in Österreich - und darüber hinaus - als Forscher, als Lehrer, als Berater und Organisator und nicht zu Letzt als Bezugsperson auf Grund seiner menschlichen Qualitäten geprägt hat. Ich selbst kann in diesem kleinen Beitrag nur einige der zahlreichen Aspekte seines Wirkens erfassen - habe freilich das Glück, Erich Streissler schon lange und aus vielen Bereichen seines akademischen Lebens zu kennen.

Als wirtschaftswissenschaftlicher Forscher umfasst der Interessen- und Tätigkeitsbereich von Erich Streissler einen weiten Bogen von Statistik und Mathematik bis hin zur Wirtschaftsgeschichte. Seine besondere Stärke besteht hier im Finden und Ausarbeiten neuer, oft verblüffender Zusammenhänge - stets dargestellt in eleganter, eindrucksvoller Form. Eine meiner ersten Erinnerungen an Erich Streissler betrifft seine Antrittsvorlesung an der Universität Wien, zu der ich als junger Assistent auf Anraten meines akademischen Lehrers Kurt Rothschild von der Linzer Universität nach Wien gefahren bin. Das an sich simple Thema der Zusammenhänge von Mittelwert und Streuung wurde in dieser Vorlesung von Streissler zu einem Feuerwerk von Ideen verarbeitet, bis hin zu philosophischen Perspektiven.

In seiner grundlegenden Forschungsorientierung sah und sieht sich Streissler wohl in der Tradition der Wiener Schule der Nationalökonomie. Dies in einer produktiven und innovativen Form, die die ganze Vielfalt dieser „Schule“ und des „liberalen Denkens" reflektiert. Dem entsprechend hält er nicht zurück mit seiner Verachtung für jene, die die „Austrian Economics“ zu einer Missionsarbeit für libertäre Dogmen reduzieren.

Mit zunehmender Lebenserfahrung hat Erich Streissler ein wachsendes Interesse und überaus profundes Wissen in Bezug auf Wirtschafts- und Dogmengeschichte entwickelt - wohl entsprechend seiner anglophilen Neigungen mit besonderem Schwerpunkt auf das Vereinigte Königreich. Streissler stand mit diesem Interesse wohl längere Zeit außerhalb der
„mainstream“-Entwicklung unseres Faches. Heute wird sichtbar, dass der Ansatz einer analytisch fundierten Wirtschaftsgeschichte wohl der relevanteste Ansatz ist, um umfassende ökonomisch-gesellschaftliche Phänomene zu Finanz- und Wirtschaftskrisen zu erfassen. Eine Fülle von hoch interessanten und aussagekräftigen Publikationen, etwa von Bernanke, Reinhart und Rogoff, Brunnermeier und anderen Autoren - interessanter Weise fast ausschließlich aus der angelsächsischen Forschungslandschaft - haben sich als die wohl aussagekräftigsten und einflussreichsten Analysen bei der wissenschaftlichen Aufarbeitung der großen Finanzkrise seit 2007 ergeben.

Erich Streisslers wissenschaftliche Liebe galt und gilt zweifellos der Theorie - aber einer Theorie, eng verknüpft mit historischem und auch institutionellem Wissen. Das zeigt sich auch im Rahmen seiner wichtigen Arbeiten im Rahmen der Österreichischen Akademie der Wissenschaften, worauf wohl an anderer Stelle eingegangen wird, wie auch in seiner Arbeit am Österreichischen Institut für Wirtschaftsforschung, dem er über Jahrzehnte hin verbunden war.

Als Lehrer und Vermittler hat Erich Streissler viele Generationen von Ökonominnen und Ökonomen geprägt - sei es als Studierende, sei es als Kolleginnen und Kollegen. Die ersten Jahre seiner Tätigkeit an der Universität Wien fielen ja in die Zeit des studentischen Aufbruches nach 1968, der gerade bei den Studierenden der Ökonomie besondere Resonanz fand. An der Wiener Universität entstand eine Gruppe mit dem einprägsamen Namen „Der rote Börsenkrach“, bestehend aus besonders talentierten, engagierten und auch fleißigen - Studentinnen und Studenten, von denen viele dann später auch überaus eindrucksvolle berufliche Karrieren erreichten. Streisslers betont liberale Positionen waren natürlich Anlass für besondere "Aufmerksamkeit" und Kritik von Seiten der „linken“ Studierenden. Im Gegensatz zu vielen anderen akademischen Lehrern stellte sich Streissler aber mit sokratischer Freude an der Diskussion dieser Kritik und wurde damit zu einer überaus wichtigen und geachteten intellektuellen Bezugsperson für Generationen von Studierenden - eine Hochach- 
tung, die auch bis heute für eine breite Gemeinschaft von Ökonominnen und Ökonomen fortlebt.

Die Liebe zur Diskussion und zur zeitweise provokativen Anregung konnte sich auch in der zeitweise sehr intensiven Mitarbeit Erich Streisslers im „Verein für Socialpolitik“, der wichtigsten Vereinigung deutschsprachiger Ökonominnen und Ökonomen, entfalten. Im Wiener Umfeld habe ich seit meiner Bestellung zum Gouverneur der Oesterreichischen Nationalbank eine regelmäßige Diskussionsrunde von Ökonominnen und Ökonomen aus der wissenschaftlichen und aus der angewandten Forschung zu Fragen der Geldund Bankpolitik ins Leben gerufen. Erich Streissler war hier stets ein aktiver, anregender und manchmal bewusst provozierender Teilnehmer, den wir heute in dieser Runde sehr schmerzlich vermissen.

Erich Streisslers pädagogisches Wirken zeigt sich auch in dem in mehreren Auflagen erschienenen Werk „Volkswirtschaftslehre für Juristen“, das er mit seiner Frau, der klugen Ökonomin Monika Streissler, verfasste, wobei einige der besonders ambitionierten Graphiken von seinem damals Chemie studierenden Sohn stammen sollen. Für Volkswirte ist es ein überaus spannendes und anregendes Buch, vielfach mit kleinen Nebenbemerkungen, deren gescheite Bosheit wohl nur geschulten Leserinnen und Lesern erkennbar wird. Viele Jus-Studenten fühlten sich von diesem Buch freilich oft überfordert und haben wohl manche schlaflose Nacht vor „dem Streissler“ verbracht. Im Rahmen einer Lehrplan-Reform wurde dann der bequeme Weg gewählt, Volkswirtschaftslehre zu einem Wahlfach im Jus-Studium zu „degradieren“, was den Absatz des Lehrbuches drastisch reduzierte (wie auch den Absatz des ergänzenden Lehrbuches von Georg Winckler und mir zur Wirtschaftspolitik).

Erich Streissler war über lange Zeit hinweg einer der bekanntesten und angesehensten Ökonomen Österreichs und dem entsprechend auch vielfach eingela-

Wien, 17. Jänner 2018 den, als Berater in wirtschaftspolitischen und wissenschaftspolitischen Gremien mitzuwirken. Er hat, soweit ich das beurteilen kann, eine sehr erfolgreiche und verantwortungsbewusste Rolle im Rahmen der Österreichsichen Akademie der Wissenschaften und, wie ich aus eigener Beobachtung weiß, jedenfalls im Rahmen des Österreichischen Instituts für Wirtschaftsforschung gespielt. Je Politik-näher ein Gremium, desto eher konnte es freilich zu Spannungen kommen, zwischen dem "freien Denken“ des Forschers und den organisatorisch-administrativen Erfordernissen, die oft die praktische Wirksamkeit von Beratungsgremien bestimmen. Ich selbst habe Konstellationen erlebt, wo Erich Streissler solche Spannungen wohl bewusst hervorgerufen und möglicher Weise auch genossen hat - und das hat in vielen Fällen auch zu meiner Sympathie und Bewunderung für Erich Streissler beigetragen. Ich sah dies immer als Ausdruck einer absolut integren Persönlichkeit basierend auf einem strengen, vielleicht manchmal etwas „altmodischen“, aber stets eindrucksvollen Selbstbewusstsein eines akademischen Lehrers. Zu diesem Selbstbewusstsein gehörte und gehört stets auch Offenheit gegenüber anderen Meinungen, wie ich etwa an dem guten freundschaftlichen Verhältnis zwischen ihm und Kurt Rothschild sehen konnte - trotz oft sehr unterschiedlichen Sichtweisen auf Ökonomie und Welt. Dieses produktive Selbstbewusstsein war und ist wohl auch begründet in einem schönen, im guten Sinn „bildungsbürgerlichen“ Familienleben.

Viele Menschen haben den langen und eindrucksvollen Lebensweg Erich Streisslers im Laufe der Zeit als Kolleginnen und Kollegen, als Schülerinnen und Schüler und als Weggefährten in verschiedenen Bereichen gekreuzt - als einer von ihnen möchte ich mit diesen Zeilen Erich Streissler Dank sagen für das Viele, das er für unsere Wissenschaft, für unser Land und für meine persönliche Entwicklung beigetragen hat!

Ewald Nowotny

Oesterreichische Nationalbank 
Mag. Dr. Stephan Schulmeister

\section{Ein „Paleoliberaler“ bringt frischen Wind}

Während sich unter den Studenten der USA, insbesondere in Kalifornien, ab Mitte der 1960er Jahre Unruhe und Protest ausbreiteten und wenig später Europa erreichten, herrschte an der Universität Wien akademische Ruhe. Erste „Lüfterln“ eines frischen Winds gingen nicht von den Studierenden der Sozialwissenschaften aus, sondern jenen der Geisteswissenschaften. Zur 600-Jahr-Feier veranstaltete die Hochschülerschaft ein großes Symposion, an dem intellektuelle Größen wie der Philosoph Ernst Bloch, die Schriftsteller Manès Sperber und Ingeborg Bachmann, der Historiker Golo Mann oder auch der SPIEGEL-Herausgeber Rudolf Augstein teilnahmen.

Die sozialwissenschaftlichen Studien waren ja erst 1965 in Österreich eingeführt worden (ein eigenes Studium der Volkswirtschaftslehre gab es vorher nicht, die Soziologie „ressortierte“ zu den Geisteswissenschaften). Allerdings mussten sich Juristen und Staatswissenschaftler ein ökonomisches Grundwissen aneignen. Daher gab es entsprechende Lehrkanzeln nur an der juridischen Fakultät. Während die Theorie von Keynes international zum Paradigma der Makroökonomie geworden war (wenn auch in stark verstümmelter Form), wurde sie in Wien lediglich unter „ferner liefen“ erwähnt.

Nur zwei Beispiele für die damalige Verkümmerung der Wirtschaftswissenschaften an der Universität Wien: Die Habilitationsschrift des international renommierten „Links-Keynesianers“ (genauer „Kaleckianers") Josef Steindl wurde in den 1950er Jahren abgelehnt, weil sie auf Englisch verfasst war (Steindl hatte 1938 nach England emigrieren müssen, war zurückgekehrt und arbeitete nunmehr am Österreichischen Institut für Wirtschaftsforschung, WIFO). Der große Ökonom Kurt Rothschild hatte auch noch in den 1960er Jahren keine Chance auf eine Professur an der Uni Wien und ging daher an die 1965 in Linz gegründete Universität.

Noch eine Anekdote zum Zustand der Ökonomik an der Uni Wien: Ein Professor für ein Nebenfach („nomina sunt odiosa“) prüft einen Studierenden in Volkswirtschaft (3. Staatsprüfung für Juristen): „Nennen Sie mir einige bedeutende tschechische
Nationalökonomen?" Der Studiosus vertraut auf das Nicht-Wissen des Professors und sprudelt einige Namen der CSSR-Eishockeymannschaft heraus (es lief gerade eine Weltmeisterschaft): „Bubik, Navratil, Nechvadal...". Sicherheitshalber gab ihm der Professor sofort ein "Sehr gut“.

In diese rückständige Ökonomen-Welt wurde (ausgerechnet) 1968 Erich Streissler als Professor für Volkswirtschaftslehre, Ökonometrie und Wirtschaftsgeschichte berufen. Er hatte sich schon mit 26 Jahren habilitiert und war 1962 - mit 29 Jahren als Professor an die Universität Freiburg berufen worden, wo auch Friedrich August von Hayek (ab 1962) lehrte. Streissler teilte dessen Glauben an die (spontan) ordnende Kraft der Märkte und die daraus resultierende Ablehnung des „Konstruktivismus“ aller - linken und nicht-linken - Weltverbesserer.

In der Zwischenzeit hatte der 1968-Wind auch die Uni Wien erreicht, und diesem Lüfterl stellte sich ein junger „Paleoliberaler“ mit größtem Vergnügen entgegen. Seine bewusst provokanten Thesen trugen zur Attraktivität seiner Lehrveranstaltungen bei. Noch wichtiger waren aber die Breite seines Wissens und der Respekt, den er den Theorien anders denkender Ökonomen zollte. So trug Streissler dazu bei, den enormen Aufholbedarf im Lehrangebot abzuarbeiten. Das betraf nicht nur die wichtigsten Entwicklungen auf dem Gebiet der makroökonomischen, also primär der keynesianischen, Theorie, sondern auch die Wiederbelebung der Tradition der „österreichischen Schule“, insbesondere die Rückbesinnung auf die Erkenntnisse ihres Gründers Carl Menger.

In seiner Zeit als renommiertester Ökonomie-Professor der Universität Wien wurde Josef Steindl (wenigstens) „re-habilitiert“, indem man ihn zum Honorarprofessor machte, mit Erwin Weissel und Van der Bellen wurden auch „Linke“ zu Universitätsprofessoren.

Für viele Jahre, insbesondere die 1970er Jahre, waren die Vorlesungen von Streissler die attraktivsten im Bereich der Wirtschaftswissenschaften, gerade auch für die linken Studenten vom „Roten Börsenkrach“, 
mit denen sich Streissler genussreiche Scharmützel lieferte. Diese setzten sich teilweise auch an meditativen Orten wie dem Zisterzienserstift Heiligenkreuz fort, wo Streissler Seminare zu ausgewählten Problemen der Ökonomie organisierte. An einem solchen über Zins und Zinspolitik durfte ich Anfang der 1980er Jahre teilnehmen, ich habe die Atmosphäre der Auseinandersetzungen noch heute in bester Erinnerung.

Dem wirtschaftswissenschaftlichen Mainstream seit den 1970er Jahren - „Neue Klassische Makroökonomik“ - konnte Streissler wenig abgewinnen, insbesondere ihren Grundannahmen: Die Vorstellung, dass die Akteure rein rationale, nur individuelle, (Eigen)Nutzen maximierende Wesen sind, die ihre (rationalen) Erwartungen an dem einzig wahren Modell orientieren, ignoriert die vielfachen Widersprüchlichkeiten von Menschen, also die „conditio humana" auf der individuellen wie gesellschaftlichen Ebene.

Gefördert durch den „marktreligiösen Fundamentalismus" hat die Beschäftigung mit Wirtschaftsgeschichte in den Ökonomie-Studien jede Bedeutung verloren. Streissler beschäftigte sich umso mehr mit dem Wechselspiel von Theorie und Realität, hielt

Wien, 19. Jänner 2018 die Vorlesung „Wirtschaftsgeschichte als angewandte Wachstumstheorie" und widmete sich verstärkt dem Studium der Klassiker, insbesondere von Adam Smith und Karl Marx.

Dazu (und nicht nur dazu) hat seine Frau Monika Streissler wesentlich beigetragen, die in jahrelanger Arbeit das ökonomische Hauptwerk von Adam Smith, dem größten der großen Ökonomen, ins Deutsche übersetzte („Der Reichtum der Völker“). Erich Streissler steuerte dazu zwei Aufsätze über Adam Smith am Beginn der Neuübersetzung bei, der weiteste Verbreitung zu wünschen ist.

Die Finanzkrise 2008 und ihre globalen Folgen stellten für Streissler - trotz seines fortgeschrittenen Alters - ein große Herausforderung dar. Gemeinsam mit Gunther Tichy publizierte er 2012 darüber den Band „How to Forecast Economic Developments During and After Crises" der Akademie der Wissenschaften, zu dem er selbst sieben Aufsätze beisteuerte. Ob sich seine Analysen und Prognosen über eine weitere Abschwächung des Wirtschaftswachstums und die zunehmende Wahrscheinlichkeit weiterer Finanzkrisen als treffend herausstellen, lässt sich jetzt noch nicht sagen. Die bisherige Entwicklung spricht dafür.

Stephan Schulmeister vorm. Österreichisches Institut für Wirtschaftsforschung 
Mag. Dr. Gertrude Tumpel-Gugerell

Sehr geehrter, lieber Herr Professor Streissler!

Ihre Einführungsvorlesung in die Volkswirtschaftslehre, Anfang der Siebziger Jahre, war für mich ein Schlüsselerlebnis. Durch Fragen stellen haben Sie uns Zusammenhänge, analytische Werkzeuge und mögliche Erklärungsansätze nahegebracht. Sie haben diese Vorlesung und nachfolgende Seminare spannend und intellektuell provozierend gestaltet.

Meine Studienwahl fiel auf Ökonomie, weil ich verstehen wollte, wie Staaten funktionieren, da ich davon ausging, dass ich von Philosophie nicht leben können würde, und weil mich Wirtschaftspolitik interessierte. Ihre Vorlesung hat eine Leidenschaft für Ökonomie entfacht, die heute, nach so vielen Jahren noch immer anhält.

Erst viel später habe ich Ihre Bewunderung für die Englische Schule der Nationalökonomie, das britische Universitätsleben und die geistreiche Debatte - nicht unbedingt eine Stärke unseres Universitätslebens - nachvollziehen können.

Sie wissen so viel über die Geschichte des ökonomischen Denkens, der Österreichischen Schule der Nationalökonomie und gleichzeitig über die Chancen und Fallstricke verschiedener Ansätze der Wirtschaftspolitik. „Ich bin ein Paleoliberaler“ - erst viel später habe ich die Bedeutung dieser Selbsteinschätzung verstanden.

Ihre ehemaligen Studenten sind erfolgreiche Akademiker, Unternehmer, Interessenvertreter, Notenbanker und Bankiers, Beamte und Journalisten geworden.

Was wir Ihnen verdanken, ist die Anleitung zu kritischem Denken, das Hinterfragen von Theorien und Ideologien und die Ermutigung, Neues zu denken.

Als ich ein Dissertationsthema abseits des Mainstreams, einen interdisziplinären Ansatz zur Erklärung ökonomischen Verhaltens abseits des homo oeconomicus wählte, waren Sie tolerant und offen, obwohl behavioral economics erst zwei Jahrzehnte später richtig Fuß fasste.

Wie sehr Sie sich als akademischer Lehrer von den Kollegen unterschieden haben, wurde erst viel später verstanden. Sie haben die Juristerei als Ausgangsbasis gesehen, haben aber mit ihren Vorlesungen Neuland beschritten - Keynesianismus, die Österreichische Schule und die Ökonometrie als Innovation.

Lieber Herr Professor, in Dankbarkeit möchte ich gratulieren und daran denken, wozu Sie mich inspiriert haben.

Wien, 21. Februar 2018

Gertrude Tumpel-Gugerell vorm. Mitglied des Direktoriums der Europäischen Zentralbank 
Erich W. STREISSLER

\section{Fifty Years in Law and Economics at Vienna}

On April 1, 2018 it will be fifty years since I was appointed as ordentlicher Professor der Rechts- und Staatswissenschaften (full professor of law and political science) at the University of Vienna.

It was a time-honoured chair to which I had been called: it was the oldest chair of political science or public economics (Lehrkanzel für Policey- und Kameralwissenschaft) in Vienna, originally created in 1763 by Maria Theresa for that all-round Enlightenment talent Joseph von Sonnenfels. In the last quarter of the $19^{\text {th }}$ century it was held by Carl Menger, one-time private tutor of the young Crown Prince Rudolf and one of the founding fathers of what was later termed the "Austrian School of Economics". The historical perspective especially of Menger has made me see economics as very much fused with legal studies, a now unusual but far from irrelevant idea.

Being appointed to a chair at a public university meant that I also became a member of one of the upper echelons of Austria's incredibly numerous class of "Beamte", civil servants. More appropriately these should be called civil controllers (of everything one can think of). In Austria, Karl Marx could never have got the idea of dividing society into only two economic and political classes: workers and entrepreneurs. Here, civil "servants" have been a "class" of their own and continue to be of social and political importance.

I was pleased to learn that my right to teach "Rechtsund Staatswissenschaften" was much wider than my duty to teach, namely "Volkswirtschaftslehre und Ökonometrie nach Maßgabe des Unterrichtsbedürfnisses" (economics and econometrics "depending on what was needed to be taught"). At the Ministry I was informed, in fact, that I would above all have to make sure that whatever was "needed" would be taught by whomever I should think fit to do this.

So it was above all for teaching that I had been appointed, and it may be my unique achievement that I taught and examined about 20000 students of law and later on also of economics up to their final university degrees. In 1975, Austrian universities were "re-organized", and the time-honoured School of
Law and Political Science (Fakultät für Rechts- und Staatswissenschaften) was split up - into a Law School and a Department of Economic and Social Sciences. New courses of studies in economics and the social sciences in general were introduced, with appropriate new degrees, and my teaching would concentrate more and more on economics in a wider sense, including economic history and especially the history of economic thought. And though initially I had been told that I would above all have to "control" that the subjects required were taught - for which purpose I persuaded the faculty to create a number of honorary (read: unpaid) professorships, all eventually filled with first rate experts - my own teaching load became steadily heavier over the years, not the least part of it being the demanding preparation of top junior economists for their Habilitation, the qualification as university teacher. But as the years went by, my work with gifted and ambitious students strengthened my resolve to teach as long as I possibly could.

Let me go back in time a little and give you the background to my appointment. In the summer of 1955, I had graduated from Vienna University Law School as Doctor juris utriusque. At that time, the traditional law school curriculum provided for only two terms of obligatory economics lectures in one's last year of studies. I delved a little deeper into the subject while on a much appreciated Fulbright Scholarship at Hamilton College in New York State in 1952/53. To my law doctorate I added a Vienna University diploma as statistician before an eye-opening term at Oxford for further instruction in economics. Happily, I was to return there several times in subsequent years, in contact above all with Professor John Hicks at All Souls College (eventually one of the early Nobel Laureates in economics). In Vienna, from 1956, I went on to study mathematics, history and psychology. But I never took the respective academic exams. For in 1959, by the time I would have been allowed to take them, I had already become a full university teacher, by Habilitation in economics. As such, I would no longer be examined by other university teachers: An examination must allow for failure - and it was assumed that one could not very well fail a "colleague", 
as I had now become. Instead, and quite unexpectedly, in 1962, I was called to a newly created Chair of Statistics and Econometrics at the Law School of the University of Freiburg in Germany - becoming the youngest full member ever of the highly respected and highly conservative faculty there. Over the next five years, I taught "what was needed" in statistics and econometrics at Freiburg and also served as Dean of the Law School for two years running. In close contact with several of the law professors I learned much about the practical, i.e. administrative, and psychological facets of faculty life and work.

Having been invited (and appointed) to take over a chair in economics at the Vienna Law School in 1968, I left Freiburg for Vienna - just before the student rebellion, read: student riots, broke out with full force at the leading German universities.

Returning to Austria, and to the chair of Carl Menger at that, I gave my inaugural lecture in early 1968 at the Vienna Law School on the topic of "Structural Economic Thought" $\left(Z f N^{1} 1969\right)$. I could show that this mode of viewing and analysing economic phenomena and problems had been peculiar to the "Austrian School of Economics" from its very beginnings in the 1870 s and was continued down to the last generation of "Austrians" to be properly so called (in 1968 some of its representatives were still active, though not in Austria, e.g. O. Morgenstern and F.A. Hayek).

So, what was and is this "structural" mode of analysis? Economists generally have to do with aggregates. Watching the performance of an economy (whether for purely theoretical reasons or for purposes of devising economic policies), the macro-economist usually regards aggregated quantities (e.g. national income, gross domestic product; exports, imports; the rate of inflation; the wage rate). There are periods in economic life when, for various reasons, successful economic policy measures can be designed by relying on such undifferentiated aggregates. This is true especially of periods of rapid economic growth. In Germany, Austria, Italy and other "Western" European countries, such growth was last experienced in the post-World-War-II reconstruction period of the 1950s and early 1960s. But in 1968 when I gave my inaugural lecture, those economies no longer boomed, and it seemed a good time to remind theoretical and practical economists of the need for looking more deeply, detailing the structure of the economic aggregates (to consider differences between various sectors, the share of incomes at different income levels, the components of "capital").

I had learned about the importance of such structural analysis not by studying the "Austrians"- Older or Younger - but rather from my first academic supervisor in Vienna, the famous statistician Wilhelm Winkler (himself a time-honoured figure: as a young academic he had been a member of the Austrian delegation at the Versailles Peace Conference in 1919, and he lived to be a hundred, after doing pioneering work in statistical demography). One of Winkler's principal tenets was: never characterize a quantitative phenomenon by only one parameter, but use (at least) two: always use a measure of dispersion in addition to a measure of localization - in statistical terms: always look at the variance as well as at the mean. It is a precept so reasonable that I have always followed it. (In fact, this may be one of the reasons why, regardless of my training in mathematics, I have never taken to "pure" economic theory, expressed in restrictive models of great mathematical refinement, but little or no connection to social reality.)

On the one hand, of course, this "structural" approach leant itself well to the teaching of law students with their inherent interest in social reality. On the other hand, and also "of course", the dissection and detailed inspection of aggregates must always be the first step on the way to considering and eventually devising policy measures in order to change the examined aggregates.

Right away, I provided a detailed example of such structural analysis in "Long-Term Structural Changes in the Distribution of Income" (also ZfN 1969) - under the then still fairly realistic assumption of economic growth. I discussed the likely development of the wage share and pointed out five possible "degrees of freedom" in that development path, which necessarily made for considerable (and progressive) variability and uncertainty. Those five were: the relationship between factor prices, the savings or investment ratio, the direction of technological progress, the factor intensity bias in consumption, and the growth rate of the labour force and its educational and skill differentials. The possible shifts occurring

Zeitschrift für Nationalökonomie 
in these five directions all had and continue to have legal as well as economic facets.

In 1971, I organized an international conference at Vienna University to celebrate the centenary of Carl Menger's Grundsätze der Volkswirthschaftslehre. It was quite an occasion, with several honorary doctorates awarded, in addition to fruitful scientific discussions. At one of those discussions a young man stood up and pointed out that all our periodical calculations of the social product, our national income accounts, would be seriously defective as long as damages to or the destruction of factors of production, of material goods, in the time period under calculation were not deducted from the "product". This observation seemed quite novel; many in the audience looked rather doubtful and not a few were inclined to take the man for a crank. But it is a fact that from the early 1970s the public became alerted to diverse negative effects of economic life and development, when pursued relentlessly. In the wake of the "Energy Crisis" of 1973 (due to an oil shortage) concern was raised about the probable consequences worldwide of the careless depletion of irreplaceable natural resources, above all about the pollution of man's most important factors of production: fresh air and clean water. To a considerable extent those effects can be quantified, and insofar as that is possible they ought regularly to be deducted from the annual "social products" or "national incomes" if those aggregates are to provide a correct or true picture of economic life. Doubts about the adequacy of National Income Accounting became more vociferous and have been fuelled ever since (I for one have criticized this deficiency up until my last papers). Very soon the topic of "Environmental Damages" in the widest sense began to be seriously discussed. And with every passing decade more scientific disciplines put it onto their research agenda.

In the 1970s, "Ecology" became a new field of research at the interface of natural and social sciences, but I must admit that for some more years mainstream economists only gave it a sceptical glance. In 1997, at the occasion of its $150^{\text {th }}$ anniversary, the Austrian Academy of Sciences (ÖAW) took up "ecology" officially with a jubilee symposium on the topic of "Social Policy and Ecological Problems of the Future". I was asked to be one of the two editors of the pertinent publication and was happy to work with the (late) limnologist Heinz Löffler, a man exemplary in the dedication to his field of research. Some years later, I was honoured by being co-opted to the ÖAW's very active Commission on Interdisciplinary Ecological Studies (KIÖS). I continue to participate in its discussions and am grateful to know about the important research its members do on urgent problems in their diverse fields.

There had been a third article derived from my inaugural lecture (also $Z f N$ 1969): on "a stochastic model of international reserve requirements during growth of foreign trade". As that title showed, I was greatly interested in monetary and financial questions in the widest sense right from my beginnings. My first course of lectures in Vienna in 1959 had dealt with the latest developments in Anglo-American monetary theory - then of the highest "news-value" to students in Vienna. After my return to Vienna, monetary theory figured regularly in my teaching programme. The problems of inflation, mostly of the creeping sort, became a major political topic of the 1970s and every economist worth his salt contributed to the discussions - while the question of exchange rates that had exercised the minds since early post-World-WarII times disappeared from the agenda (for a while) when the Bretton Woods system of fixed exchange rates was abolished. Still later, students had to be introduced to Chicago-born "monetarism" as a system of economic policy. Its pros and cons were heatedly discussed among scholars and practitioners alike, and not least among my advanced students. From the early 1990s the question of a common currency for the EEC countries loomed large, and from my list of publications I see that the words "speculation" and "financial markets" first crop up in various titles in 1998 and 2000. In 2009, I presented my explanation of the 2007/08 Crisis in the USA in a lecture to the ÖAW, and I followed this up by more detailed analysis after the (US government) "Commission on the Causes of the Financial and Economic Crisis in the United States" had published its official report in 2011.

In lectures and seminars around the millennium, I returned to the - to my mind highly important and too often neglected - topic of reserves, now in the context of globalization, a novel manifestation of "growth of world trade". I considered those reserves (of sovereign states and of major financial institutions) glaringly insufficient in some cases. Time and again I pointed to the problem that free-wheeling exchange rates would no longer give a correct picture of the relative values of currencies and thus must 
misrepresent the true state of some major economies, above all the USA, the world's by far biggest debtor country. Its problems are still very much with us ...

After the institution of a proper department of economic and social sciences in 1975, a group of gifted students there felt they had to show some spirit of rebellion and at least to put into doubt whatever was on the economics curriculum, by references to Karl Marx and what (I presumed) they presumed were his teachings, just as their German coevals had started to do a few years earlier. As a conscientious teacher I felt I had to find out what Das Kapital contained. So I spent a cold and rainy summer on it, three fat tomes in all, in the imposing (East German) MEGA edition. When the students realized that I could now quote to them "what Marx had really said", they seemed impressed - although with their spirit of discussion a little damped. Did I profit from studying this momentous work? Yes, because I realized "firsthand", as it were, the enormous simplifications upon which Marx had erected his system. An insight that became useful (for purposes of comparison) when I turned to the study of German and Austrian economic thought of the $19^{\text {th }}$ century. My knowledge of Marx (and a thorough knowledge of Keynes, to boot) always stood me in good stead with the various generations of students I taught. I never made a secret of my personal liberal convictions (a liberalism strictly observing legal bounds), but those were not held against me. Students learned that I was familiar with the socio-economic tenets of important European and Anglo-American scholars of the most diverse political views and ideologies.

This was due to my historical bent. In the latter half of my fifty years in Vienna I became more and more involved with questions pertaining to the history of economic thought and discovered hitherto unrealized connections between the ideas of major $19^{\text {th }}$ century German economists (especially Rau, but also Hermann and Roscher) and those of the "Older" Austrians (especially Menger, but also Böhm-Bawerk and Wieser) and also the teachings of Alfred Marshall in Cambridge (whose most famous pupil would be Keynes).

Among the numerous research projects to which I contributed one stands out for me, because of its quite unexpected results. In the mid-1980s, the late Brigitte Hamann, that admirable biographer of Crown Prince Rudolf (and others), had discovered and transcribed the handwritten notebooks in which Rudolf, then seventeen, had taken down the private lectures on economics given to him by Carl Menger (who then corrected, if necessary, what the pupil had written from memory). Ms Hamann offered me those transcriptions to make what I could of them. To my surprise, Menger had lectured the boy not only on the basic concepts of economics, but had also discussed questions of economic policy - giving his own opinions on them, too. In his published works, Menger never pronounced on economic policy. The Crown Prince's notebooks are unique in their content for they show Menger as a man of liberal persuasions in the Adam Smith vein. A few years later I convinced a generous British publisher, Edward Elgar, of their singular value; and he published them in a handsome bilingual edition.

Glancing through my numerous papers on policy issues, the "issues of the day", as it were, there is also one that stands out - in this case for the political reverberations it was to have. It was a two-part newspaper article in early 1990 that a Viennese weekly had asked for. The issue of the day then was German Reunification. Chancellor Kohl had told the "Western" Germans that this would not cost them anything much. The weekly wanted to find out if that optimistic statement could possibly be correct. Would I give them my ideas on the possible cost of German Re-unification? I would and I did. After serious calculations and with an array of logical arguments I presented my results: the expense eventually to be expected surprised even me. But what surprised me even more was the stir that those two articles caused in German political circles. Some weeks after the publication of my estimates, I received an invitation (an order, rather) to present myself at the German Embassy at such and such a time where an official envoy from high up in the Bonn hierarchy wished to talk to me. I decided to disappoint him and ignored the order. Only much later I understood the sensation I had caused: I had been the only one to speak out against the German Chancellor. Alas, my estimations proved to be realistic. 
Theoretical or mathematical statistics is a large and very general subject. Only in my first five years as professor in Freiburg I had to teach it to students. But as related to economics, statistics became of increasingly greater importance over the fifty years of my Vienna professorship. With the help of international statistics, we are nowadays sufficiently informed about incomes worldwide. By now much more important than generally shrinking average growth rates of national incomes are the mostly increasing inequalities of different incomes, i.e. the variances of incomes: Less than a hundred very large incomes (including holdings of personal wealth) actually comprise more than half of aggregate global incomes-cum-wealth. This subject and the concomitant phenomena of income inequalities and poverty have interested me more and more over the past decade. Although I could no longer work on them, I was gratified to learn from the publications of Amartya Sen, Tony Atkinson and Angus Deaton that those first-rate scholars have done pioneering work in this field, presenting significant facts to those who care to know them. I can only hope and wish that their important work may be continued by the next generations of scholars and will result in appropriate and successful political measures.
One has to distinguish between incomes and wealth. Then three facts are notable: (1) The global wealth distribution is such that less than a hundred individuals or families hold as much wealth as the entire poorer half of mankind, with no indication of a change in this relationship. (2) The global income distribution is highly unequal, of course; but at least in the $21^{\text {st }}$ century this inequality has decreased a little: In the so-called threshold economies a middle class is beginning to establish itself. It will contribute to a higher social product than heretofore and will claim its appropriate share thereof. (3) By way of contrast, at the same time the income distribution within the highly developed economies has clearly become more unequal, again with no indication of a change in that tendency.

The problems of global income differentials are serious. The problems of climate change and global warming, however, are life-threatening. People all over the planet - scholars, experts of all kinds, and men and women in practical life, high and low - dedicate themselves to alleviating them. It is a race against time, against egoism, and against the self-willed myopia of the powers that be. Can it be won? 
Erich W. STREISSLER

\section{Schriftenverzeichnis / Bibliography}

$\begin{array}{ll}\text { AB } & \text { Artikel in Buch / article in book } \\ \text { AZ } & \text { Artikel in Zeitschrift / article in journal } \\ \text { B } & \text { Buch oder Broschüre / book or brochure } \\ \text { BS } & \text { Beitrag zu Sammelwerk / article in encyclopedia or monograph } \\ \text { HBB } & \begin{array}{l}\text { Herausgabe eines Buches mit Vorwort und/oder eigenem Beitrag / editor with own } \\ \text { contribution }\end{array} \\ \text { SV } & \text { Schriftlich vorgelegter Vortrag / lecture in manuscript form } \\ \text { Anzeiger } & \text { Anzeiger der philosophisch-historischen Klasse der Österreichischen Akademie der } \\ & \text { Wissenschaften } \\ \text { ESHET } & \text { European Society for the History of Economic Thought } \\ \text { HdSw } & \text { Handwörterbuch der Sozialwissenschaften } \\ \text { NDB } & \text { Neue Deutsche Biographie } \\ \text { NWB } & \text { Neue Wissenschaftliche Bibliothek } \\ \text { SVS } & \text { Schriften des Vereins für Socialpolitik } \\ \text { SWSO } & \text { Schriftenreihe des Wirtschaftswissenschaftlichen Seminars Ottobeuren } \\ \text { WPBl } & \text { Wirtschaftspolitische Blätter } \\ \text { ZfN } & \text { Zeitschrift für Nationalökonomie }\end{array}$

1957

"Population Change and Economic Growth", ZfN 17 (1957), 332-340.

1958

"Shackle and the Theory of Risk", ZfN 18 (1958), 208222.

\section{9}

„Die volkswirtschaftliche Produktionsfunktion in dynamischer Betrachtung", ZfN 19 (1959), 86192. [Habilitationsschrift / Thesis of Habilitation]

1960

Möglichkeiten und Grenzen einer produktivitätsorientierten Lohnpolitik. Österreichisches Institut für Wirtschaftsforschung, Wien 1960, 64 S.

„Wirtschaftspolitische Grundsätze des österreichischen Kartellgesetzes und der Tatbestand der Gesamtwirtschaftlichen Rechtfertigung“, Wiener
Studien zur Wirtschafts- und Gesellschaftspolitik, Heft 2, 1960, 12-51.

$\mathrm{AZ}$

„Erwartungen, Unsicherheit und Risiko“ (mit W.

Weber), HdSw Bd. 3, 1961, 330-339.

BS

\section{2}

„Statistik“, Herders Staatslexikon Bd. 7, 1962, 663671.

BS

„Trend“, Herders Staatslexikon Bd. 7, 1962, 10301033.

„Was ist Ökonometrie, wozu dient sie und was hat sie bisher geleistet?" Allgemeines Statistisches Archiv 46 (1962), 35-57.

$\mathrm{AZ}$

\section{4}

„Nutzen“ (mit W. Weber), HdSw Bd. 8, 1964, 1-19.

„Österreich“ (mit Th. Pütz), HdSw Bd. 8, 1964, 60-73.

BS

"Entrepreneurial Behaviour in Austria" (mit P. Hoschka), Metrika 8 (1964), 155-184.

AZ 


\section{5}

„Die gesamtwirtschaftlichen Funktionen der Werbung“, ZfN 25 (1965), 243-277.

AZ

\section{6}

Konsum und Nachfrage (Hrg. mit M. Streissler), NWB Bd. 13, Köln - Berlin 1966, 591 S. HBB

„Das Konsumentenverhalten als Inflationsursache“, ZfN 26 (1966) [Festschrift für Alexander Mahr], 329-348.

$\mathrm{AZ}$

\section{8}

"A Test of Allais' Version of the Quantity Theory of Money" (mit H. Frisch und H. Schmalzl), ZfN 28 (1968), 234-245.

\section{9}

„Zur Anwendung von Gemeinwohlvorstellungen in richterlichen Entscheidungen“ in: Zur Einheit der Rechts- und Staatswissenschaften. Ringvorlesung der Rechts- und Staatswissenschaftlichen Fakultät der Universität Freiburg, Freiburger Rechtsund Staatswissenschaftliche Abhandlungen Bd. 27, Karlsruhe 1969, 1-47.

$\mathrm{HBB}$

"Hayek on Growth: A Reconsideration of his Early Theoretical Work" in: E. Streissler, G. Haberler, F.A. Lutz, F. Machlup (Hrg.), Roads to Freedom, Essays in Honour of Friedrich A. von Hayek, London 1969, 245-285.

$\mathrm{HBB}$

"Long-Term Structural Changes in the Distribution of Income", ZfN 29 (1969), 39-110.

$\mathrm{AZ}$

"Structural Economic Thought - On the Significance of the Austrian School Today", ZfN 29 (1969), 237-266. [Antrittsvorlesung Teil I / Inaugural lecture part I]

AZ

"A Stochastic Model of International Reserve Requirements During Growth of World Trade", ZfN 29 (1969), 347-370. [Antrittsvorlesung / Inaugural lecture part II]

AZ

"A Reexamination of the Haavelmo-Bias in the Least Squares Estimation of the Keynesian Consumption Function", Metrika 14 (1969), 164-182. AZ
1970

Pitfalls in Econometric Forecasting. Research Monograph 23, Institute of Economic Affairs, London 1970, 80 S.

\section{B}

„Privates Produktiveigentum - Stand und Entwicklungstrends der Auffassungen in kapitalistischen Ländern" in: Eigentum - Wirtschaft - Fortschritt, Walter Raymond Stiftung Bd. 12, Köln 1970, 76133.

$\mathrm{AB}$

1971

„Die Bedeutung der Investitionen für das Wirtschaftswachstum“, WPBl 18 (1971), 5-14. $\quad$ AZ

\section{2}

"Investment Stimulation and the Hierarchy of Individual Plans" in: W. Schmitz (Hrg.), Convertibility, Multilateralism and Freedom, Essays in Honour of Reinhard Kamitz, Wien - New York 1972, 49-65.

1973

Die schleichende Inflation als Phänomen der politischen Ökonomie. Basler wirtschaftswissenschaftliche Vorträge Nr. 8, Zürich 1973, 83 S.

„Das Monopol wirtschaftsempirischer Wahrheit Denkstil und Verantwortlichkeit“ in: H. Seidel, H. Kramer (Hrg.), Wirtschaftsforschung in Österreich: eine Standortbestimmung, Wien 1973, 27-39.

$\mathrm{AB}$

"Menger's Theories of Money and Uncertainty - A Modern Interpretation" in: J.R. Hicks, W. Weber (Hrg.), Carl Menger and the Austrian School of Economics, Oxford 1973, 164-189.

"Macht und Freiheit in der Sicht des Liberalismus" in: H.K. Schneider, Ch. Watrin (Hrg.), Macht oder ökonomisches Gesetz, SVS N.F. 74/II, Berlin 1973, 1391-1426.

"To What Extent was the Austrian School Marginalist?" in: R.D.C. Black, A.W. Coats, C.D.W. Goodwin (Hrg.), The Marginal Revolution in Economics, Durham NC 1973, S. 160-175.

„Wozu brauchen wir Gewinne?", Der Handelsvertreter und Handelsmakler, 25 (1973), 631-634. AZ 
„Die Wiener Nationalökonomie und ihr Erbe“, Die Presse, 30.6.1973 (Jubiläumsbeilage).

„Der Bedarf an Währungsreserven bei wachsendem Welthandel" in Beiträge zur Stabilitätspolitik, Dr.Stigleitner-Schriftenreihe 13, Wien 1973, 3-12.

„Vorwort“ zu K. Läufer, W.D. v. Lucius, P. Richter, Ökonometrie des Zinssatzes, Stuttgart 1973.

HBB

„Preisgesteuerte Wirtschaft - Preisgesteuerte Gesellschaft", Mitteilungen der List-Gesellschaft Fsc. 8/4 (1973), 67-87.

1974

„Zur Normalität zurück“, Economy - Das österreichische Wirschaftsjournal, Nr. 2 (1974), 18-25.

„Konsumtheorie“, Handwörterbuch der Absatzwirtschaft, Sp. 1086-1104; Enzyklopädie der Betriebswirtschaftslehre IV, Stuttgart 1974. BS

„Verteilungstheorie außerhalb der neoklassischen Preistheorie" in: G. Bombach, B.S. Frey, B. Gahlen (Hrg.), Neue Aspekte der Verteilungstheorie, SWSO Bd. 2, Tübingen 1974, 47-57.

1975

„Bessere Stabilisierungspolitik durch Regelmechanismen oder regelgebundenes Verhalten?" in: B. Gahlen, H.K. Schneider (Hrg.), Grundfragen der Stabilitätspolitik, SWSO Bd. 3, Tübingen 1975, 171-188.

„Hilflos? Inflation und Wirtschaftswissenschaften“, Die Aussprache 16/8,9 (1975), $4 \mathrm{f}$.

$\mathrm{AZ}$

„Wieviel Monetarismus kann die österreichische Wirtschaftspolitik vertragen?" WPBl 22/3 (1975), 21-31.

„Liberale Wirtschaftsordnung - aktueller denn je; Versuch einer ,materialistischen' Geschichtsinterpretation“ in: P. Harbusch und D. Wick (Hrg.), Marktwirtschaft, Stuttgart 1975, 5-16.
1976

„Welche Inflationstheorie bietet die Wirtschaftswissenschaft?", Gemeinwirtschaft H. 2/1975, 29-32.

Zur Relativierung des Zieles der Geldwertstabilität (mit L. Beinsen, St. Schleicher, H. Suppanz und Stellungnahme von K.W. Rothschild), Kommission für wirtschaftlichen und sozialen Wandel 100, Göttingen 1976, 356 S.

\section{B}

"Sozialpartnerschaft und Gewinne“, WPBl 23/4 (1976), 40-50.

$\mathrm{AZ}$

„Preissystem, Eigentumsrechte und politische Wahlprozesse als soziale Entscheidungsfindungen“, WPBl 23/5 (1976), 47-73.

$\mathrm{AZ}$

"Personal Income Distribution and Inflation" in: H. Frisch (Hrg.), Inflation in Small Countries, Lecture Notes in Economics and Mathematical Systems 119, Berlin - Heidelberg - New York 1976, 343-356.

$\mathrm{AB}$

Einleitung der Generaldiskussion in: G. Bombach, B. Gahlen, A.E. Ott (Hrg.), Ausgewählte Probleme der Wachstumspolitik, SWSO Bd. 4, Tübingen 1976, 429-441.

BS

„Diffusion des technischen Fortschritts und Wettbewerb“ in: G. Bombach, B. Gahlen, A.E. Ott (Hrg.), Probleme der Wettbewerbstheorie und -politik, SWSO Bd. 5, Tübingen 1976, 63-76.

BS

„Die geistigen Wurzeln - Kann sich die spätmarxistische Wirtschaftskritik auf Marx berufen?" in: A. Rummel (Hrg.), Der Spätmarxismus und sein Publikum - Anspruch und Wirklichkeit, Bonn aktuell, Stuttgart 1976, 50-75.

$\mathrm{AB}$

\section{7}

"What Kind of Microeconomic Foundations of Macroeconomics are Necessary?" in: G.C. Harcourt (Hrg.), The Microeconomic Foundations of Macroeconomics, London - Basingstoke 1977, 96132. 
„Tischrede“ in: B. Külp, H.-D. Haas (Hrg.), Soziale Probleme der modernen Industriegesellschaft, SVS N.F. 92/II, Berlin 1977, 989-994.

„Die Transmission monetärer Impulse über den Kreditmarkt - zur Bedeutung der Kreditrationierung und ihrer institutionellen Voraussetzungen in Europa" (mit G. Tichy) in: W. Ehrlicher (Hrg.), Probleme der Geldmengensteuerung, SVS N.F. 99 Berlin 1978, 145-195.

„Fiskalismus kontra Monetarismus“, Quartalshefte der Girozentrale 12/4 (1977), 11-24.

"Measures to Promote Capital Formation" in: H. Giersch (Hrg.), Capital Shortage and Unemployment in the World Economy, Tübingen 1977, 255267.

„Investitionsförderung und Strukturpolitik“ in: G. Bombach, B. Gahlen, A.E. Ott (Hrg.), Probleme des Strukturwandels und der Strukturpolitik, SWSO Bd. 6, Tübingen 1977, 447-460.

„Zu W. Rall, Stärkere Inflation bei stetigerem Wachstum?", Jahrbuch für Nationalökonomie 191 (1977), 557-558.

\section{8}

„Der gesamtwirtschaftlich optimale Lohnertrag - Skizze eines komplexen Problems" (mit M. Streissler) in: W. Engels (Hrg.), Neue Wege in der Arbeitswelt, Horst Knapp zum 60. Geburtstag, Frankfurt - New York 1978, 156-179.

„Inflation und Investitionen“, CA-Wirtschaftsberichte 13/4 (1978), 6-17.

„Europäische Arbeitslosigkeit als Dauerschicksal?“ in Europäische Arbeitslosigkeit als Dauerschicksal - oder brauchen wir einen anderen Arbeitsmarkt? Bergedorfer Gesprächskreis, Protokoll Nr. 60 (1978).

„Theorien der Konsumfunktion. Ein kritischer Überblick im Lichte der jüngsten Rezession“ in: G. Bombach, B. Gahlen, A.E. Ott (Hrg.), Neuere Entwicklungen in der Theorie des Konsumentenverhaltens, SWSO Bd. 7, Tübingen 1978, 1-31.

BS

„Bemerkungen zu dem Referat von H. Luckenbach, Neuere Ansätze in der Mikroökonomischen Konsumtheorie“, ebenda / ibid., 236-243. BS
1979

„Die Statistik in Ökonomie und Ökonometrie“, Mitteilungsblatt der Österreichischen Gesellschaft für Statistik und Informatik, 9/36 (1979), 155-157.

$\mathrm{AZ}$

„Die Pepita“ (I und II) in: O.v. Trebeis (Hrg.), Nationalökonomologie, Tübingen 1979, 70-77. [Wiederabdruck von „Einen Damm gegen die Inflation“, Die Presse 5.1.1971]

„Die volkswirtschaftliche Bedeutung der Werbung in einer Unternehmerwirtschaft " in: Österreichische Werbewirtschaftliche Gesellschaft (Hrg.), Werbung und Marktwirtschaft, 26. Werbewirtschaftliche Tagung, Wien 1979, 37-44. BS

"Growth Models as Diffusion Processes", Kyklos 32 (1979), I: H. 1/2, 251-269, II: H. 3, 571-586. AZ

„Inflationswirkungen“ in: A. Woll (Hrg.), Inflation Definitionen, Ursachen, Wirkungen und Bekämpfungsmöglichkeiten, München 1979, 84-95. AB

Der Stellenwert der Gewinne in deutscher Wirtschaftstheorie und deutscher Wirtschaftspolitik. Festvortrag anlässlich des 50jährigen Firmenjubiläums der Frankfurter Versicherungs-AG am 25. September 1979 in Frankfurt am Main, o.O., o.J.

$$
\text { B }
$$

"Four Diffusion Models of the Distribution of Income" in: K. Laski, E. Matzner, E. Nowotny (Hrg.), Beiträge zur Diskussion und Kritik der neoklassischen Ökonomie. Festschrift für Kurt W. Rothschild und Josef Steindl, Berlin - Heidelberg 1979, 93-104.

\section{0}

Zur Theorie marktwirtschaftlicher Ordnungen (Hrg. mit Ch. Watrin), Tübingen 1980. Darin: „Einleitung“ 1-12 sowie „Kritik des neoklassischen Gleichgewichtsansatzes als Rechtfertigung marktwirtschaftlicher Ordnungen“, 38-69. HBB

„Die Knappheitsthese - Begründete Vermutungen oder vermutete Fakten?" in: H. Siebert (Hrg.) Erschöpfbare Ressourcen, SVS N.F. 108, Berlin 1980, 9-36.

BS

"Models of Investment-Dependent Economic Growth Revisited" in: R.C.O. Matthews (Hrg.), Economic Growth and Resources, Bd. 2, London Basingstoke 1980, 145-163.

$\mathrm{AB}$ 
„Finanzmärkte bei steigendem Einkommen und Vermögen - Zinskonstanz oder Marktzins als gesamtwirtschaftliche Strategie“, Wirtschaftsanalysen (Erste Österreichische Spar-Casse), 4 (1980), 9-31.

AZ

„Zu einer einfachen makroökonomischen nichtlinearen Investitionsfunktion; oder: der Münchhauseneffekt" in: G. Bombach, B. Gahlen, A.E. Ott (Hrg.), Neuere Entwicklungen in der Investitionstheorie und -politik, SWSO, Bd. 9, Tübingen 1980, 345-354.

BS

"Die gesellschaftliche Rolle der Gewinne“, Der Unternehmer H. 4 (1980), 4ff.

A. Klose, W. Mantl, V. Zifkovits (Hrg.) Katholisches Soziallexikon, Innsbruck - Wien - München Graz - Köln, 2. Aufl 1980. BS Darin die Einträge / the entries:

Keynes und Keynesianismus, Sp. 1328-1333

Nationalökonomie, Sp. 1856-1874

Produktivität und Rentabilität, Sp. 2253-2258

Statistik, Sp. 2943-2950

Volkswirtschaftliche Gesamtrechnung, Sp. 3287-3294

Wirtschaftswachstum, Sp. 3423-3430

1981

„Investitionsförderung und Wirtschaftswachstum“ (Zu G. Tichys Beitrag „Wie wirkt das österreichische System der Investitionsförderung?"), Quartalshefte der Girozentrale, 16/III (1981), 21-27.

„Adam Smith: Der Adam oder nur Wachstum? - Paradoxa einer wissenschaftlichen Revolution" in: F. Neumark (Hrg.), Studien zur Entwicklung der ökonomischen Theorie I, SVS N.F. 115/I, Berlin 1981, 9-52.

„Theorie der Wirtschaftsstruktur: Was ist Gegenstand der Strukturberichterstattung?" in: Strukturberichterstattung der Wirtschaftsforschungsinstitute, Tübingen 1981, 1-28.

“Schumpeter's Vienna and the Role of Credit in Innovation", in: H. Frisch (Hrg.), Schumpeterian Economics, Eastbourne 1981, 60-83.

„Zum Zusammenhang zwischen Korruption und Wirtschaftsverfassung (Korruption im Vergleich der Wirtschaftssysteme)“ in: Ch. Brünner (Hrg.),
Korruption und Kontrolle, Wien - Köln - Graz 1981, 199-228.

„Zu einer Theorie der Einkommensverteilung bei Unsicherheit" in: F. Klanberg und H.J. Krupp (Hrg.), Einkommensverteilung, NWB 92, Königstein/T. 1981, 85-102.

$\mathrm{AB}$

"Strukturelle Innovationsanreize - ein volkswirtschaftlicher Ansatz", Z-Perspektiven (Berichte Analysen), Wien 1981.

\section{$\mathrm{AZ}$}

"On Probabilistic Models in Economic Theory" in: M. Heidelberger und L. Krüger (Hrg.), Probability and Conceptual Change in Scientific Thought, 22. Report Wissenschaftsforschung, Bielefeld 1981, 165-184.

$\mathrm{AB}$

“Introduction", Empirica 2 (1981), 151-154. AZ

\section{2}

Neue Strömungen in der Nationalökonomie. Eine Übersicht (herausgegeben von der CreditanstaltBankverein), Wien 1982, 23 S.

„Der Schutz der Vermögensrechte des Bürgers gegenüber dem Staat aus ökonomischer Sicht" [Referat auf der 2. Sozialrechtslehrertagung], Schriftenreihe des deutschen Sozialrechtsverbandes, Bd. XXIII, Wiesbaden 1982, 16-32.

„Das Ende des Keynesianismus“, WPBl 29 (1982), 78-93.

AZ

\section{3}

„Hans im Glück - Katallaktische und andere Bemerkungen zu einem Hausmärchen der Brüder Grimm“" (mit M. Streissler) in: H. Enke, W. Köhler, W. Schulz (Hrg.), Struktur und Dynamik der Wirtschaft. Beiträge zum 60. Geburtstag von Karl Brandt, Freiburg 1983, 17-37.

$\mathrm{AB}$

„Konservative Wirtschaftspolitik in der Krise“, WPBl 30 (1983), 31-43.

AZ

„Die ,Neue Klassische Makroökonomie'“, Quartalshefte der Girozentrale 18/1 (1983), 9-22. AZ

„Stagnation - Analyse und Therapie“ in: G. Bombach, B. Gahlen, A.E. Ott (Hrg.), Makroökonomik heute: Gemeinsamkeiten und Gegensätze, SWSO, Bd. 12, Tübingen 1983, 457-476. 


\section{4}

Grundzüge der Volkswirtschaftslehre für Juristen (mit M. Streissler), Wien 1984, 406 S. [2., unveränderte Auflage 1986]

„Vollbeschäftigungspolitik in der Stagnation“ in: St. Koren u.a. (Hrg.), Politik für die Zukunft. Festschrift für Alois Mock, Wien - Köln - Graz 1984, 193-201.

\section{5}

Außenwirtschaft bei Ungewissheit (Hrg. mit H. Hesse und G. Tichy), Tübingen 1985. Darin „Einleitung“, 1-9, sowie „Disequilibrium Theory and International Trade", 44-66.

$\mathrm{HBB}$

„Ein Multiplikator-Akzelerator-Modell mit langfristiger Konsumfunktion“, in: D. Cansier und D. Kath (Hrg.), Öffentliche Finanzen, Kredit und Kapital. Festschrift für Werner Ehrlicher, Berlin 1985, 345-355.

$\mathrm{AB}$

„Bemerkungen zur Geschichte der Spartheorien“ (mit W. Neudeck) in: W. Ehrlicher und D.B. Simmert (Hrg.), Der Volkswirtschaftliche Sparprozeß. Beiheft 9 zu Kredit und Kapital, Berlin 1985, 3-25.

$\mathrm{AB}$

"Austrian School" in: A. und J. Kuper (Hrg.), The Social Science Encyclopedia, London 1985, 53-54.

„Zinsen und Zinspolitik in Österreich“, WPBl 32 (1985), 117-119.

\section{6}

„Arma virumque cano - Friedrich von Wieser, der Sänger als Ökonom“ in: N. Leser (Hrg.), Die Wiener Schule der Nationalökonomie, Wien - Köln Graz 1986, 83-106.

$\mathrm{AB}$

"Are there Intellectual Precursors to the Idea of Second Best Optimization?" (mit W. Neudeck), ZfN Suppl. 5 (1986), 227-242.

„Die Wiener Schule der Nationalökonomie“ in: P. Berner, E. Brix, W. Mantl (Hrg.), Wien um 1900. Aufbruch in die Moderne, Wien 1986, 77-80.

$\mathrm{AB}$

„Effizienz- und vertragstheoretische Versuche der Erklärung der Arbeitslosigkeit", Quartalshefte der Girozentrale 1/1986, 27-33.
1987

„Wieser, Friedrich, Freiherr von“, The New Palgrave A Dictionary of Economics, Bd. 4, London 1987, 921-922.

„Kapitalmarkt und Altersvorsorge“, Kapitalmarkt und Finanzierung, SVS N.F. 165, Berlin 1987, 447-463.

„Konjunkturtheorie“, R. Herzog, H. Kunst, K. Schlaich (Hrg.), Evangelisches Staatslexikon, 3. Aufl. (wie 1. und 2. Aufl.), Stuttgart 1987, Sp. 1849-1853. BS

„Die Fiktion des Austrokeynesianismus“, WPBl 34 (1987), 714-724.

$\mathrm{AZ}$

\section{8}

"New Information-Theoretic Approaches to Labour Market Theory" in: J.A. Kregel u.a. (Hrg.), Barriers to Full Employment, Houndsmill - London 1988, 48-65.

"The Intellectual and Political Impact of the Austrian School of Economics", History of European Ideas 9 (1988), 191-204.

Weltweite Steuerreformen: Konsequenzen für Österreich. Marktwirtschaftliche Schriften des Carl Menger Instituts, Wien 1988, 66 S.

„Was kann die Geldpolitik von den neuesten Entwicklungen der Geldtheorie lernen?" in: G. Bombach, B. Gahlen, A.E. Ott (Hrg.), Geldtheorie und Geldpolitik, SWSO, Bd. 17, Tübingen 1988, 3-45.

\section{9}

„Der Unternehmer in der deutschen Nationalökonomie des 19. Jahrhunderts“ in: B. Gahlen u.a. (Hrg.), Wirtschaftswachstum, Strukturwandel und dynamischer Wettbewerb. Ernst Helmstädter zum 65. Geburtstag, Berlin - Heidelberg 1989, 17-33.

„Carl Menger (1840-1921)“ in: J. Starbatty (Hrg.), Klassiker des ökonomischen Denkens II, München 1989, 119-143.

$A B$

1990

"Menger, Böhm-Bawerk, and Wieser: The Origins of the Austrian School" in: K. Hennings, W. Samuels (Hrg.), Neoclassical Economic Theory, 1870 to 
1930, Boston - Dordrecht - London 1990, 151189.

"Carl Menger on economic policy: the lectures to Crown Prince Rudolf" in: B.J. Caldwell (Hrg.), Carl Menger and his legacy in economics, History of Political Economy 22 (1990), Annual Supplement, 107-130.

"The influence of German economics on the work of Menger and Marshall", ebenda / ibid., 31-68.

"Carl Menger, der deutsche Nationalökonom in: B. Schefold (Hrg.), Studien zur Entwicklung der ökonomischen Theorie X, SVS N.F. 115/X, Berlin 1990, 153-195.

„La moneta buona scaccia quella cattiva“, Biblioteca della libertà XXV (1990), 69-89.

„Soziale Marktwirtschaft und parlamentarische Demokratie - Die ökonomischen Aspekte" in: Soziale Marktwirtschaft und Parlamentarische Demokratie - ein Symposion der Ludwig-ErhardStiftung, Stuttgart - New York, 7-28.

„Schumpeter in Graz - Gedankenexperimente eines jungen Österreichers“ (mit M. Streissler) in: G. Bacher, K. Schwarzenberg, J. Taus (Hrg.), Standort Österreich - Über Kultur, Wirtschaft und Politik im Wandel, Graz 1990, 545-566.

„Unsere goldlose Goldwährung“ in: J.M. Graf von der Schulenburg, H.W. Sinn (Hrg.), Theorie der Wirtschaftspolitik, Festschrift zum fünfundsiebzigsten Geburtstag von Hans Möller, Tübingen 1990, 106-128.

„Die Wurzeln der ,Österreichischen Schule’ der Nationalökonomie in der deutschen Wirtschaftswissenschaft des 19. Jahrhunderts“, Anzeiger, Jg. 126, Wien 1990, 169-186.

\section{1}

"What Kind of Economic Liberalism May We Expect in ,Eastern' Europe?", East European Politics and Societies, 5 (1991), 195-201.

AZ

„Probleme der Unternehmensbesteuerung im Licht der Principal Agent Theorie" (mit W. Neudeck) in: D. Rückle (Hrg.), Aktuelle Fragen der Finanzwirtschaft und der Unternehmensbesteuerung, Festschrift für Erich Loitlsberger, Wien 1991, 483507.
„Österreichs Wechselkurs und die Probleme einer Währungsunion" in: H. Kienzl (Hrg.), Österreichs Wirtschafts- und Währungspolitik auf dem Weg nach Europa, Festschrift für Maria Schaumayer, Wien 1991, 141ff.

$\mathrm{AB}$

„Porträt Friedrich August von Hayek“ in: O. Molden (Hrg.), Zeitwende - Vision und Wirklichkeit, Europäisches Forum Alpbach 1991, 264ff. AB

„Manchesterliberalismus und Wirtschaftsliberalismus“ (zum Beitrag von A.F. Utz „Zum Begriff des Eigentumsrechts“) in: A.F. Utz (Hrg.), Die Katholische Soziallehre und die Wirtschaftsordnung, Trier 1991, 291ff.

“Genius or Engines? On Jürg Niehans' History of Economic Technique", Journal of Institutional and Theoretical Economics 147 (1991), 379-395. AZ

"Saving, Income Distribution and German Union (Comment)" in: A.B. Atkinson, R. Brunetta (Hrg.), Economics for the New Europe, Basingstoke - London 1991, 209-215.

\section{2}

"Hayek on Information and Socialism", WPBl 39 (1992), 258-283.

"Towards an Economics of Transition - Lessons from the Economic Transformation of Eastern Europe and the Experience of the Marshall Plan" in: $\mathrm{H}$. Albeck (Hrg.), Wirtschaftsordnung und Geldverfassung, Symposium zum 65. Geburtstag von Norbert Kloten, Göttingen 1992, 74-98.

$\mathrm{AB}$

„Hundert Jahre Sozialenzykliken - Eine wirtschaftswissenschaftliche Analyse“ in: H. Schambeck, R. Weiler (Hrg.), Der Mensch ist der Weg der Kirche, Berlin 1992, 77-117.

$\mathrm{AB}$

"Good Money Driving Out Bad: A Model of the Hayek Process in Action" in: E. Baltensperger, H.W. Sinn (Hrg.), Exchange-Rate Regimes and Currency Unions, Basingstoke - London 1992, 203-223.

$\mathrm{AB}$

\section{3}

„Das Problem der Internalisierung“ in: H. König (Hrg.), Umweltverträgliches Wirtschaften als Problem von Wissenschaft und Politik, SVS N.F. 224, Berlin 1993, 87-110.
BS 
Unmöglichkeit und Notwendigkeit der Wirtschaftspolitik als bleibendes Dilemma. Walter-Adolf JöhrVorlesung 1993, St. Gallen 1993, 41 S.

„Deutschland, Deutschland über alles?", Angewandte Sozialforschung 18/4 (1993/94), 221-235. [Nachdruck aus Wochenpresse (Wien) Teil I: 14/1990, 48-53; Teil II: 15/1990, 42-45]

\section{4}

Carl Menger's Lectures to Crown Prince Rudolf of Austria (mit M. Streissler), Aldershot 1994, vii, 228 S. [zweisprachig / bilingual edition]

"Hayek on Information and Socialism" in: M. Colonna, H. Hagemann, O.F. Hamouda (Hrg.) The Economics of F.A. Hayek, Bd. II: Capitalism, Socialism, and Knowledge, Aldershot 1994, 47-75. [Nachdruck aus WPBl 39 (1992)]

"The Influence of German and Austrian Economics on Joseph A. Schumpeter" in: Y. Shionoya, M. Perlman (Hrg.), Schumpeter in the History of Ideas, Ann Arbor 1994, 13-38.

$\mathrm{AB}$

"German Predecessors of the Austrian School", P.J. Boettke (Hrg.), The Elgar Companion to Austrian Economics, Aldershot 1994, 493-499.

$\mathrm{AB}$

Grundzüge der Volkswirtschaftslehre für Juristen (mit M. Streissler), 3. überarbeitete Auflage, Wien 1994, 457 S.

„Wilhelm Roscher als führender Wirtschaftstheoretiker", Vademecum zu einem Klassiker der Historischen Schule, Düsseldorf 1994, 37-121.

$\mathrm{AB}$

“Theoretical and Methodological Positions of German Economics in the Middle of the Nineteenth Century" (mit K. Milford), History of Economic Ideas 1 (1993/94), 43-79.

$\mathrm{AZ}$

„Sozialevolutorische Ethik und Privatrecht" in: F. Bydlinski, Th. Mayer-Maly (Hrg.), Die ethischen Grundlagen des Privatrechts, Wien - New York 1994, 131-155.

"Interesse und Utilitarismus" in: W. Schmitz, R. Weiler (Hrg.), Interesse und Moral - Gegenpole oder Bundesgenossen?, Berlin 1994, 169-181. AB

„Menger, Carl, Nationalökonom“, NDB Bd. 17, Berlin 1994, 72-74.

BS

„Zur Lehre von den Absatzkrisen. Oder: Gibt es in der relevanten Konjunkturtheorie und -politik in den letzten 140 Jahren etwas Neues?" in: E. Matzner, E. Nowotny (Hrg.), Was ist relevante Ökonomie heute?, Marburg 1994, 111-121.

„Die Neue Selbständigkeit - Herausforderung und Chance“, WPBl 41 (1994), 368-382.

$\mathrm{AZ}$

„Kapitalmarkt und Wirtschaftswachstum“, WPBl 41 (1994), 516-526.

„Wirtschaft und Währung“ in: A. Wala (Hrg.), Der Schilling - Ein Spiegel der Zeiten, Wien 1994, 3647.

"The Problem of Internationalization of and Liability for Environmental Damages" in: K. Mackscheidt, D. Ewringmann, E. Gawel (Hrg.), Umweltpolitik mit hoheitlichen Zwangsabgaben, Berlin 1994, 245-260.

„Carl Mengers Vorlesungen aus politischer Ökonomie für Kronprinz Rudolf", Anzeiger 131. Jg., Wien 1994, 15-44. BS

1995

"Comment on Part IV" in: Ch.T. Saunders (Hrg.), Eastern Europe in Crisis and the Way Out, Basingstoke - London 1995, 365-367.

$\mathrm{AB}$

„Die Grenzproduktivitätstheorie der deutschen Protoneoklassik unter besonderer Berücksichtigung von Johann Heinrich von Thünen“ in: H. Rieter (Hrg.), Studien zur Entwicklung der ökonomischen Theorie XIV, SVS N.F. 115/XIV, Berlin 1995, 1741.

"Increasing returns to scale and the prospects of small-scale enterprises", Journal of Economic Studies 22 (1995), 16-25.

$\mathrm{AZ}$

\section{6}

„Ökonomische Aspekte einer Energiesteuer (Internalisierung von Kosten, Wohlfahrtstheorie) “ in: T. Ritt (Hrg.), Ökologische Steuerreform, Informationen zur Umweltpolitik 116, Kammer für Arbeiter und Angestellte für Wien, Wien 1996, 8-22.

$\mathrm{AZ}$

„Der Wirtschaftsliberalismus in Mitteleuropa: Umsetzung einer wirtschaftspolitischen Grundkonzeption?" in: E. Brix, W. Mantl (Hrg.) Liberalismus - Interpretationen und Perspektiven, Wien - Köln - Graz 1996, 135-179.
BS 
„Was ist Arbeit heute? Wandlungen eines Inhaltes und Begriffes" in: F. Schneider, R. Strasser, K. Vodrazka (Hrg.), Leben ohne Arbeit?, Wien 1996, 97-117.

\section{7}

„Philipp Wilhelm von Hörnigk und die wirtschaftstheoretischen und -politischen Vorstellungen des Kameralismus" (mit M. Streissler), in: Vademecum zu einem Klassiker absolutistischer Wirtschaftspolitik, Düsseldorf 1997, 139-242. AB

„Der Wirtschaftsliberalismus in Mitteleuropa: Umsetzung einer wirtschaftspolitischen Grundkonzeption?" in: E. Streissler (Hrg.), Studien zur Entwicklung der ökonomischen Theorie XVI, SVS N.F. 115/XVI, Berlin 1997, 5-13, 81-127. HBB

[ebenso Hrg. der Bände / also editor of the following volumes: SVS N.F. 115/XVII und 115/ XVIII, Berlin 1998, jeweils mit Vorwort, sowie / with prefaces, and SVS N.F. 115/XIX, Berlin 2002]

HBB

„Die dritte Phase der WWU in ihrer Bedeutung für Österreich“ in: H. Handler (Hrg.), Vom Schilling zum Euro. Wirtschaftspolitische Aspekte des Übergangs, Bundesministerium für wirtschaftliche Angelegenheiten, Wien 1997, 116-122. AB

„Wachstums- und Umweltpolitik“ (mit W. Neudeck), in: E. Nowotny, G. Winckler (Hrg.), Grundzüge der Wirtschaftspolitik Österreichs, Wien 1997, 166-213.

$\mathrm{AB}$

„Die Wirtschafts- und Sozialwissenschaftler in der Österreichischen Akademie der Wissenschaften" in: O. Hittmair, H. Hunger (Hrg.), Akademie der Wissenschaften. Entwicklung einer österreichischen Forschungsinstitution, Wien 1997, 99-115.

Kommentar zu: Richard B. Freeman „Arbeitsplatzbeschaffung und Einkommensbildung in Europa und den USA: Auf dem Weg ins 21. Jahrhundert", in: Zukunftsforum im Bundeskanzleramt (Hrg.), Bundespressedienst, Wien 1997, 67-73. BS

Friedrich Benedikt Wilhelm von Hermann: Anatomie einer wissenschaftlichen Verwandlung, Sitzungsberichte der Bayerischen Akademie der Wissenschaften, Phil.-Hist. Klasse, Heft 9, München 1997, 44 S.

\section{8}

„Beratung als diktatorisches Unterfangen - der wirtschaftspolitische Berater im demokratischen Entscheidungsprozess" in: M. Steiner (Hrg.), Wirtschaftspolitische Beratung heute, Frankfurt/M. 1998, 57-77.

$\mathrm{AB}$

„Neue finanzpolitische Aufgaben des Staates“, Conturen 2/1998 [Tagungsband zum Symposium „Wirkungen und Herausforderungen der ökonomischen Globalisierung“], 7-23.

BS

„Zur Problematik der Erklärung von Devisenkursen. Ein kritischer Überblick“ in: E. Baltensperger (Hrg.), Spekulation, Preisbildung und Volatilität auf Finanz- und Devisenmärkten, SVS N.F. 257, Berlin 1998, 9-54.

BS

\section{9}

„Das Verhältnis von Ökonomie, Ökonomiepolitik und Ökologie" [Referat am Festsymposium der Akademie der Wissenschaften anlässlich ihres 150jährigen Jubiläums, 15., 16. Mai 1997] in: H. Löffler, E. Streissler (Hrg.), Sozialpolitik und Ökologieprobleme der Zukunft, Wien 1999, 339-364.

HBB

"Wilhelm Roscher (1817-1894)" in: J.G. Backhaus (Hrg.), The Elgar Companion to Law and Economics, Cheltenham 1999, 425-434.

BS

Rezension von K.J. Vaughn, Austrian Economics in America: the Migration of a Tradition (Cambridge 1998), ZfN 70/2 (1999), 210-212.

$\mathrm{AZ}$

„Friedrich von Wiesers wissenschaftliche Grundperspektive“ in: H. Hax (Hrg.), Vademecum zu einem Klassiker der Österreichischen Schule, Düsseldorf 1999, 25-31.

$\mathrm{AB}$

Zwei Striche Symbolisch? - €uropa als monetaristische Wirtschaftsordnung (Lorenz-von-Stein-Gedächtnisvorlesung, Kiel, 15.11.1999). Hrg. v. Lorenzvon-Stein-Institut für Verwaltungswissenschaften an der Christian-Albrechts-Universität zu Kiel, Kiel 1999, 32 S.

Adam Smith, Untersuchung über Wesen und Ursachen des Reichtums der Völker (übersetzt von / translated by M. Streissler, Hrg. E. Streissler), 2 Bde., Düsseldorf 1999, 924 S.

$\mathrm{HBB}$ 


\section{0}

"Apparent progress due to forgetfulness or reinterpretation" in: St. Boehm u.a. (Hrg.), Is there progress in economics? Knowledge, Truth and the History of Economic Thought [ESHET Konferenz, Graz, 26.02.2000], Cheltenham 2002, 136-141.

„Internationale Finanzmärkte aus einer von Hayek inspirierten Sicht", ORDO - Jahrbuch für die Ordnung von Wirtschaft und Gesellschaft 51 (2000), 75-96.

„Eucken und die wirtschaftliche Lenkungsfunktion freier Finanzmärkte“ in: B. Külp, V. Vanberg (Hrg.), Freiheit und wettbewerbliche Ordnung, Freiburg 2000, 345-359.

„Wechselkurse und Weltfinanzmärkte“, WPBl 47 (2000), 378-389 [gekürzte Fassung des Semestereröffnungsvortrages vor der Rechts- und Staatswissenschaftlichen Fakultät der Universität Bonn am 22.10.1999 / shortened version of semester-opening lecture delivered at the Bonn Law School, October 22, 1999].

„Rudolf Hilferding und die Österreichische Schule der Nationalökonomie“ in: H. Hax (Hrg.), Vademecum zu einem Klassiker der Beziehungen zwischen Industrie- und Finanzkapital, Düsseldorf 2000, 53-65.

„Wirtschaft und Ethik - ein Widerspruch - Bleibt der Mensch auf der Strecke?", Schriftlich vorgelegter Vortrag, 28.11.2000, Salzburg, Academia Europaea.

„Endogenität und Neutralität des Geldes in theoriegeschichtlicher Perspektive“, Festsymposium für Karl Häuser: Exogeneity and Endogeneity of Money in the History of Economic Thought, Center of Financial Studies, 27.10.2000. Frankfurt/M. SV

„Thünen-Vorlesung: 61/2 - Wechselkurse“ [Rostock 1998] in: R. Hauser (Hrg.), Die Zukunft des Sozialstaats, SVS N.F. 271, Berlin 2000, 79-111. BS

\section{1}

"Comment on Monetary and Financial Instability" in: A. Leijonhufvud (Hrg.), Monetary Theory as a Basis for Monetary Policy, London 2001, 245254.
"Financial Institutions and Technological Progress: An historical perspective", Oesterreichische Nationalbank, Volkswirtschaftliche Tagung 2001, 2-10.

„Wirtschaftliche Entscheidungstheorie als Angelpunkt der Österreichischen Schule der Nationalökonomie" in: K. Acham (Hrg.), Geschichte der österreichischen Humanwissenschaften, Wien 2001, 309-318.

$\mathrm{AB}$

"Rau, Hermann and Roscher: Contributions of German Economics Around the Middle of the $19^{\text {th }}$ Century", European Journal of the History of Economic Thought 8/3 (2001), 1-20.

\section{2}

"On the Neutrality of Money Or the Story of Anacharsis the Scythian” in: G. Chaloupek u.a. (Hrg.), Ökonomie in Theorie und Praxis. Festschrift für Helmut Frisch, Heidelberg 2002, 331-358. AB

Exchange Rates and International Financial Markets An asset-theoretic perspective with Schumpeterian innovation, London - New York 2002, 148pp. B

"Smith and Ricardo on Comparative Advantage in Relation to Factor Movements" [Presidential address], ESHET Konferenz, Rethimno, Kreta 2002.

\section{3}

„Die wirtschaftspolitische Enthaltsamkeit der Wiener Schule der Nationalökonomie", Schriftlich vorgelegter Vortrag, Symposium: Die österreichische Schule der Nationalökonomie, Klagenfurt, September 2003.

SV

„Wie prägen ökonomische Theorien Europa?", Schriflich vorgelegter Beitrag / manuscript, Österreichischer Wissenschaftstag, Semmering, 25.10.2003.

“Adam Smith's Ultimate ,Invisible Hand': Content and Rhetoric" [Presidential address], Schriftlich vorgelegter Vortrag, ESHET Konferenz, Paris 2003.

SV

„Pütz, Theodor“, NDB Bd. 21, Berlin 2003, 2-3. BS

"Wilhelm Roscher", in: J.G. Backhaus (Hrg.), The Elgar Companion to Law and Economics, Cheltenham 2003. 
"Financial Institutions and Technological Progress: An Historical Perspective", Schriftlich vorgelegter Vortrag, ESHET Konferenz, Lecce 2003. SV

„Nationalökonomik als Naturlehre: Roscher als Wirtschaftspolitiker verglichen mit dem ,liberalen' Rau“, SVS N.F. 115/XX, Berlin 2003, 13-39.

\section{4}

"Friedrich A. von Hayek's monetary analysis" in: E. Brix, H. Schmidinger (Hrg.), Europa im Zeichen von Wissenschaft und Humanismus, Wissenschaft, Bildung, Politik, Bd. 7, Wien 2004. AB

"Ideas of the Austrian - or Vienna - School of Economics for Financial Markets" [Presidential address], ESHET Konferenz, Treviso 2004. SV

\section{5}

"Hermann als Wirtschaftstheoretiker" in: M. Pix (Hrg.), Zeitschrift für die bayerische Sparkassengeschichte, München 2005, 17-42.

$\mathrm{AZ}$

"The Influence of German Economists" in: T. Raffaelli, G. Becattini, M. Dardi (Hrg.), The Elgar Companion to Alfred Marshall, Cheltenham 2005. [verfasst 2002 / written in 2002]

„Schumpeter in Graz - Mögliche Deutungen eines ,unmöglichen' Ökonomen“, Schriftlich vorgelegter Festvortrag zur Eröffnung des Grazer Schumpeter Center, November 2005 / lecture delivered at the opening of the Graz Schumpeter Center, in manuscript form.

SV

\section{7}

„Das Wechselspiel monetärer und realer Entwicklungen in der Weltwirtschaft", Schriftlich vorgelegter Vortrag am 13.09.2007 / manuscript, Landesverteidigungsakademie, Wien.

„Die Bedeutung des Leistungsbilanzsaldos für die Erklärung der Wechselkurse“ (mit Th. Singer), Vortrag vor der Wirtschaftsuniversität Wien, 14.12.2007 / lecture at the University of Economics, Vienna, in manuscript form.

\section{8}

"Forecasts for the Development of Economic Resources (Food and Energy)", Schriftlich vorgelegter Vortrag / lecture in manuscript form, KIÖS, ÖAW, 2008.

SV

"Capital and Time” in: R. Scazzieri u.a. (Hrg.), Markets, Money and Capital - Hicksian Economics for the Twenty-First Century, Cambridge 2008, 367381.

$\mathrm{AB}$

\section{9}

„Nationalökonomie ohne Ethik“ und „Auf dem Weg zu Logik und Politikwissenschaft“, in: H. Pribyl (Hrg.), Wirtschaft und Ethik, Heiligenkreuz 2009, 21-32, 43-57.

Rezension von Jesús Huerta de Soto, "The Austrian School: Market Order and Entrepreneurial Creativity (Cheltenham 2008)", The European Journal of the History of Economic Thought, 16 (2009), 205-213.

"Evolution: How Far was Darwin an Economist?", Schriftlich vorgelegter Vortrag / lecture in manuscript form, Darwin Symposium, ÖAW, März 2009.

SV

“The Financial Market Crisis”, Schriftlich vorgelegter Vortrag / lecture in manuscript form, Gesamtsitzung der ÖAW, 17.01.2009.

SV

"The Crisis in Perspective: The Return to Macroeconomic Criteria in Evaluating Economic Performance", Schriftlich vorgelegter Vortrag, Fakultät für Wirtschaftswissenschaften, Universität Wien, 15.06.2009 / lecture in manuscript form, Department of Economics, Vienna University. SV

\section{0}

„Wirtschaftswissenschaft ohne Werte? Ökonomische Grundfragen am Beispiel von Klima- und Umweltproblemen“, Schriftlich vorgelegter Vortrag / lecture in manuscript form, Ökumenische Sommerakademie Kremsmünster, 14.07.2010. SV 


\section{2}

How to Forecast Economic Developments During and After Crises (mit G. Tichy), Phil.-hist. Klasse, Denkschriften Bd. 429, ÖAW, Wien 2012, 128 S.

"Financial Crises and Sovereign Bankruptcies“, Schriftlich vorgelegter Vortrag / lecture in manuscript form, Gesamtsitzung der ÖAW, 18.04.2012.

\section{3}

"International Financial Markets and Long-Term Environmental Problems", KIOES Opinions 1, 1-13, 2013.

\section{4}

"Mean and Variance and Their Changes in Economic Development", KIOES-Opinions 2, 1-13, 2014.

\section{5}

"National Accounting, Global Warming, and other Challenges for Long-term Economic Forecasting", KIOES-Opinons 4, 1-10, 2015.

\section{7}

"An American Transformation - John Bates Clark's ,Pure Theory' of ,Natural' Wages and Interest" in: H. Hagemann (Hrg.), Studien zur Entwicklung der ökonomischen Theorie XXXII, SVS N.F. 115/ XXXII, Berlin 2017, 183-206. 
Erich W. StreissLeR

\section{Biographie}

1933 geboren 08.04. in Wien

1951 Matura am BRG Stubenbastei, Wien I, Beginn des Jus-Studiums an der Universität Wien

1952/53 Fulbright-Stipendium (Hamilton College, NY)

1955 Promotion zum Dr. juris, Universität Wien

1956 Diplom als geprüfter Statistiker, Universität Wien

ab 1957 Universitätsassistent am Lehrstuhl für Wirtschafts- und Sozialpolitik

1959 Habilitation aus Volkswirtschaftslehre, Universität Wien

Beginn der Vorlesungstätigkeit an der Rechts- und Staatswissenschaftlichen

Fakultät der Universität Wien

1961 und mehrmals bis in die 80er Jahre (trimesterweise) Forschungsaufenthalte an der Universität Oxford

ab1961 Teilbeschäftigung am Österreichischen Institut für Wirtschaftsforschung

1962 September: Ernennung zum o. Professor für Statistik und Ökonometrie an der Rechts- und Staatswissenschaftlichen Fakultät der Albert-Ludwigs-Universität, Freiburg/B.

1965 Ablehnung eines Rufes auf einen o. Lehrstuhl für Statistik an der Johann-Wolfgang-Goethe-Universität, Frankfurt/M.

1965-1967 Dekan der Rechts- und Staatswissenschaftlichen Fakultät in Freiburg

1968 Ernennung zum ordentlichen Professor der Rechts- und Staatswissenschaften an der Universität Wien

ab 1968 intensive Vorlesungs- und Prüfungstätigkeit an der Juristischen Fakultät

1973/74 Dekan der Juristischen Fakultät

ab 1975 [infolge Neuorganisation der Universitäten] Mitglied der Fakultät für Sozial- und Wirtschaftswissenschaften, später Fakultät für Wirtschaftswissenschaften; hauptsächliche Lehr- und Prüfungstätigkeit aber weiterhin an der Juristischen Falkultät, solange dort VWL Pflichtfach blieb (insgesamt mehr als 20.000 Studenten gelehrt und geprüft)

seit den wiederholt fachlich einschlägige journalistische Tätigkeit (ORF Club Zwei, Tages-

80er Jahren zeitungen)

intensive Mitarbeit in drei wissenschaftlichen Ausschüssen der (Deutschen) Gesellschaft für Wirtschafts- und Sozialwissenschaften (Verein für Socialpolitik) [Theoretischer Ausschuss, Geldausschuss und vor allem Dogmenhistorischer Ausschuss]

Gründungs- und später Vorstandsmitglied sowohl der European Economic Association (EEA) wie der European Society for the History of Economic Thought (ESHET) 
1983 (Januar - Juni) Lehrtätigkeit als Distinguished Visiting Professor of Austrian Studies an der Universität Stanford CA

1986 Wahl zum korrespondierenden Mitglied der Österreichischen Akademie der Wissenschaften (ÖAW)

Ernennung zum „Börserat“ (Funktion an der Wiener Börse bis zu deren rechtlicher Neuordnung)

1991 Wahl zum Vizepräsidenten des Österreichischen Instituts für Wirtschaftsforschung (Funktionsdauer: 1991-2008)

1992 Wahl zum wirklichen Mitglied der ÖAW

Ehrenmitglied der Ungarischen Akademie der Wissenschaften

Korrespondierendes Mitglied der Bayerischen Akademie der Wissenschaften

1998-2008 Vorstandsmitglied der International Economic Association (IEA), ab 2001 Schatzmeister derselben

1998 Verleihung der Ehrenmedaille der Bundeshauptstadt Wien in Gold

$2000 \quad$ Preis der Stadt Wien für Geistes- und Sozialwissenschaften

2001 Emeritierung Universität Wien

2001-2013 durchgehend intensive Lehr- und Prüfungstätigkeit sowie Betreuung zahlreicher Bachelor-, Master- und Doktorarbeiten an der (nunmehr) Fakultät für Wirtschaftswissenschaften der Universität Wien

2011 Erstellung eines Berichtes an die ÖAW über den offiziellen Financial Crisis Enquiry Report der US-amerikanischen Regierung

2013 April (nach Erreichen des 80. Geburtstags): Beendigung der Lehr- und Prüfungstätigkeit an der Universität Wien

Mai: Diagnose schwerer Krankheit, seither Dialysepatient 
Erich W. StreissLeR

\section{Biography}

1933 born April 8 in Vienna

1951 graduation from high-school (BRG Stubenbastei, Vienna), enrolment at Vienna University (VU) Law School

1952/53 Fulbright Scholarship (Hamilton College, NY)

1955 Dr. juris, VU

1956 university diploma as “Statistician”, VU

from 1957 "Assistant" at the Chair of Economic and Social Policy, VU

1959 Habilitation (qualification as university teacher) in economics, VU lecturer at VU Law School, where economics at that time was an obligatory subject

1961 (and several more times up into the 1980s) visiting scholar at the University of Oxford, thanks to the good offices of Professor John R. Hicks; part-time employment at the Austrian Institute of Economic Research

1962 September: appointed Full Professor of Statistics and Econometrics at the Law School of the University of Freiburg/Germany

1965-1967 Dean of the Freiburg Law School

1968 appointed "Full Professor of Law and Political Science" at VU Law School [this title is no longer extant; historically at VU "Political Science" more or less equalled "Economics"]

1973/74 Dean of the Law School

from 1975 [reorganization of Austrian university statutes] member of the newly created Faculty of Social and Economic Sciences, later Department of Economics of VU; but main teaching and examination activities continued at the Law School, as long as economics was an obligatory subject in the Law School curriculum; taught and examined a total of more than 20000 students

from the active in three of the Research Committees of the German Association of Economic 1980s and Social Sciences [Gesellschaft für Wirtschafts- und Sozialwissenschaften - Verein für Socialpolitik], viz. the committees on economic theory, on money and currency, and above all the committee on the history of economic thought

founding member of the European Economic Association (EEA) and the European Society for the History of Economic Thought (ESHET)

1983 January to June: Distinguished Visiting Professor of Austrian Studies at the University of Stanford CA elected as "Corresponding Member" of the Austrian Academy of Sciences (ÖAW)

1991 elected as vice-president of the Austrian Institute of Economic Research (a function held until 2008) 
1992 elected as "Full Member" of ÖAW

Honorary Member of the Hungarian Academy of Sciences

Corresponding Member of the Bavarian Academy of Sciences

1998-2008 on the Committee of the International Economic Association (IEA), from 2001 IEA-Treasurer

2001 Professor emeritus, VU

2001-2013 continued full teaching programme and examinations (Bachelors, Masters and Ph.D.s) at the Department of Economics, VU

2013 April: university activities ended

May: serious illness diagnosed; since then dialysis patient 

